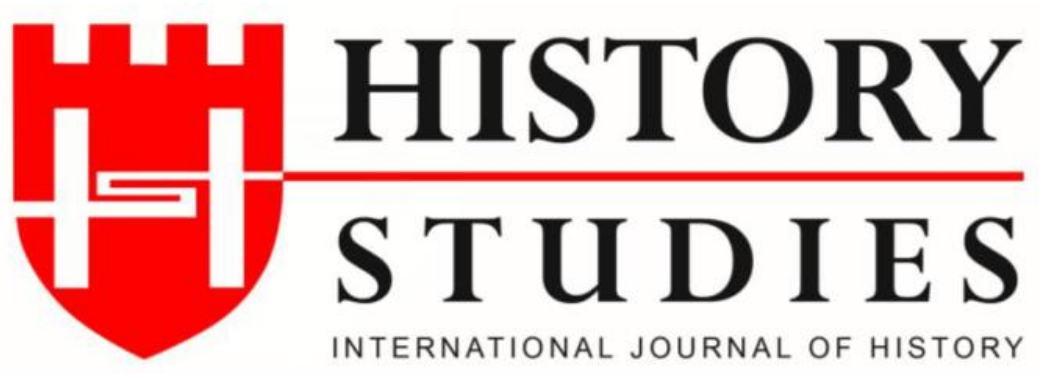

ISSN: 13094173 (Online) 1309 - 4688 (Print)

Volume 12 Issue 3, June 2020

DOI Number: 10.9737/hist.2020.852

Araştırma Makalesi

Makalenin Geliş Tarihi: 25.02.2020 Kabul Tarihi: 27.05.2020

Atıf Künyesi: Ahmet Yılmaz - Ali Toraman, “Türk Kültüründe At Kuyruğu Bağlama ve Kesme Geleneği Üzerine Bazı Tetkikler", History Studies, 12/3, Haziran 2020, s. 745-763.

\title{
Türk Kültüründe At Kuyruğu Bağlama ve Kesme Geleneği Üzerine Bazı Tetkikler
}

Some Examinations on The Tradition of Horsetail Tying and Cutting in Turkish Culture

\author{
Dr. Ahmet Yilmaz / Dr. Ali Toraman \\ ORCID No: 0000-0003-3825-2660 / 0000-0001-8513-9148 \\ Amasya Üniversitesi
}

\begin{abstract}
Öz: Türklerin tarihte atı evcilleștiren ilk toplum olduğu genel kabul gören bir nazariyedir. Bu durum hem yazılı ve sözlü kaynaklarla hem de arkeolojik verilerle desteklenmektedir. Özellikle arkeolojik verilerden elde edilen bilgiler, atın evcilleştirilmesini ve günlük hayatta kullanılmasını M.Ö. 3000 yıllarına kadar dayandırmaktadır. Atı evcilleştiren Türkler maddi ve manevi kültürlerinin her alanında ata ayrı bir yer vermişlerdir. Kazılardaki ilk bilgilere göre başlangıçta gıda maddesi, binek hayvanı ve yük hayvanı olarak kullanılan atlar daha sonra inanç sistemi içerisinde de kendisine yer edinmiş, çeşitli dini uygulamaların başrollerinden birisi olma özelliğine sahip olmuştur. Türk tarihinde hanedanlar ve devletler zaman zaman değişmiştir ancak kültürel özellikler kendini korumuş ve Türk tarihi boyunca nesilden nesle aktarılmıştır. Bu bağlamda ilk Türkler arasında görülen adetlerin sonraki dönemlerde de devam ettiği aşikardır. Bu çalışmada tarihi süreç içerisinde Türk kültüründe uygulanan at kuyruğu bağlama ve kesme geleneği üzerinde durulacaktır.
\end{abstract}

Anahtar kelimeler: At, kuyruk, süvari, Türk kültürü.

Abstract: It is a widely accepted theory that Turks are the first society that domesticated horses. This theory is both supported by written and verbal sources and archaeological data. Especially the findings obtained from archaeological data, base the domestication and use of horses in daily life as far as B.C. 3000. Turks who domesticated horses attached significant importance to the horses in every field of their material and non-material cultures. According to the initial findings in the excavations, horses which were used as food products, mount, and beasts of burden then had their place in the belief system and became the leading roles of various religious practices. In Turkish history, dynasties and empires changed occasionally, however, cultural features preserved themselves and was passed down from generation to generation throughout the Turkish history. In this context, it is obvious that traditions observed in early Turkish societies continued in the following periods. In this study, horsetail tying and cutting tradition which was applied in Turkish culture throughout history will be discussed.

Keywords: Horse, tail, cavalry, Turkish culture. 


\section{Giriş}

Tarihte, Türkler kadar atla içli-dışlı olmuş bir millet daha yoktur. Türkler için at; binek hayvanıdır, yük hayvanıdır, en önemli savaş aracıdır, oldukça değerli bir ticari maldır, en makbul kurban hayvanıdır, etinden ve sütünden faydalanılan gıda maddesidir, derisinden faydalanılan giyim-kuşam maddesidir. Bütün bunlar genel olarak atın günlük hayattaki maddi yerini göstermektedir. Bununla birlikte atın bir de Türk manevi hayatında yeri vardır ki, bunu hem kurganlardaki buluntularda hem de atla ilgili çeşitli ritüellerde görmekteyiz. Atların dini inanç gereği birtakım ritüeller çerçevesinde kurganlara gömülmesinin yanı sıra, günlük hayatta ve özellikle savaşlarda ve ölümle ilgili durumlarda atlara çeşitli anlam ve manalar yüklenen uygulamalar da yapılmıştır. Bunlardan birisi de atın kuyruğunun bağlanması ve kesilmesi âdetidir. Bu uygulama eski çağlardan itibaren özellikle savaş durumunda ve ölüm durumunda Türk inanç hayatında görülmüştür. Bu geleneğin en eski örneklerini kurgan kazıları sonucu elde edilen atlar üzerindeki işlemlerde ve çeşitli eşyalar üzerindeki at figürlerinde görmekteyiz.

\section{1- Türk Kültüründe Atlara Ait En Eski İzler}

Yukarıda değindiğimiz üzere at, Türk toplumunda oldukça büyük öneme sahiptir ve kültürümüzün her alanında kendisine yer edinmeyi başarmıştır. Atın bu konuma gelmesi her anlamda insan hayatını kolaylaştırması, özellikle bozkır hayatının her alanında insana yardımcı olabilmesinden kaynaklanmıştır. Atın insan hayatına girmesi konusu ise geçmişten beri tartışılmaktadır ve hala tartışma konusu olan bir meseledir. Bu konuda çeşitli fikirler öne sürülmekle birlikte genel kabul edilen görüş, atın Türkler tarafından evcilleştirilmiş olmasıdır. Her ne kadar çalışmanın konusu atın evcilleştirilmesi olmasa da konunun anlaşılması açısından kısaca ve sadece genel hatlarıyla bu konuya da değinmeye çalışacağız. Zira atın evcilleştirilmesi başlı başına bir çalışma konusu oluşturmaktadır.

Atın evcilleştirilmesinin ilk defa Türkler tarafından gerçekleştirildiğini kaydeden İ. Kafesoğlu, bu konuda farklı yazarları örnek göstererek şu bilgileri verir: "W. Koppers'a göre atın ehlileştirilmesini "atl1-çoban" kültürün sahibi olan Türklere atfetmek gerekir. F. Flor da atın Türklerin ataları tarafından insanlık hizmetine sokulduğunu belirtmiştir. Tanınmış Viyanalı din ve kültür tarihçilerinden W. Schmidt ise Orta Asya'da oturan ve çok eski bir zamanda avcılık hayatından hayvanları ehlileştirmeye geçen ve ata ilk binen kavmin Türkler olduğunu kabul etmiştir. O. Menghin de bozkırlı halkın at yetiştirme kültürü ile en yüksek seviyeye ulaştı̆̆ını söylemiştir." "Bu örnekler de atın evcilleştirilmesi konusunda Türkleri ve Türklerin yaşadığı coğrafyayı işaret etmektedir.

O. Lattimore de atın evcilleştirilmesi konusunda Tuva ve Baykal bölgesi civarındaki grupları işaret etmektedir. Ona göre bu bölgedeki ormanlarda yaşayan ve ren geyiği besleyen gruplar kuzey ve kuzeybatı Moğolistan bozkırlarına doğru kısa gezintiler yapıp avcılık ve toplayıcılık yapmaktaydılar. Bozkıra açılan bu gruplar, daha sonra at, koyun gibi diğer hayvanları da evcilleştirmişlerdir. Diğer taraftan Rusya, Çin, Orta Asya vahalarında avcılık ve toplayıcılık yapan insanlar bulunduğunu, bunların tarımla da uğraştıkları hatta tarımda sulama yöntemlerini de bildiklerini kaydeder ve bu bahsi geçenlerin tarımdan sonra at ve koyun gibi hayvanları evcilleştirdiklerini dile getirir. ${ }^{2}$

\footnotetext{
${ }^{1}$ İbrahim Kafesoğlu, “At”, TDV İslam Ansiklopedisi, Cilt 4, Türkiye Diyanet Vakfı Yayınları, İstanbul 1991, s.27.

2 Owen Lattimore, Studies in Frontier History Collected Papers 1928-1958, Oxford Üniversitesi Yayınları, Londra 1962, s.142-144.
} 
Arkeolojik veriler ise buluntulardan yola çıkarak daha çok Altay-Minusinsk bölgesini işaret eder. Türk kültür coğrafyasındaki günümüze kadar yapılan kazılara göre at kalıntılarına sıklıkla rastlanan en erken devir Afanasyevo kültürüdür ve bu kültürün yaşadığı coğrafya da AltayMinusinsk bölgesi olarak kaydedilir. ${ }^{3}$ M.Ö. 3000 yıllarında başlayan ve M.Ö. 1700'lü yıllara kadar devam eden Afanasyevo kültürü Güney Sibirya'nın en eski kültür tabakası olma özelliği göstermektedir. Bölgede kazı yapan arkeolog N. Yermolova, Sibirya'nın güneyinde evcil hayvan olarak at beslenmesine Afanasyevo döneminde başlandığını kaydeder. ${ }^{4}$ Eldeki verilere göre, Afanasyevo kabileleri Sibirya'nın güneyinde hayvancılıkla uğraşan en eski kültür tabakasıdır. Buradaki kazılarda ele geçirilen materyallere bakarak inek, at, koyun, keçi ve geyik beslendiği anlaşılmaktadır. Arkeolojik kazılarda Afanasyevo öncesi katmanlarda at kalıntılarına ait izlere rastlanmadığından ilk at besiciliğinin bu dönemde başladığı sonucuna varılmıştır. ${ }^{5}$ Diğer taraftan Afanasyevo kalıntılarında elde edilen hayvan kemikleri arasında en çok sayıyı oluşturanlardan birisi de at kemikleridir. ${ }^{6}$ Kazı çalışmaları neticesinde bu kültürün bütün tabakalarında büyük oranda at kemikleri bulunmuştur. ${ }^{7}$ Söz konusu oran Altay'daki birtakım yerlerde \%60'a ulaşır. Altay’daki Balıktıyul, Kara-Teneş, Küçük Dugan, Aşağı Sooru adındaki arkeolojik alanlarda bulunan evcilleştirilmiş hayvanlara ait kalıntıların \%60'1 at kemiklerinden oluşur. $^{8}$ Altay'daki Kulanda bölgesinde, M.Ö. III binli yıllara ait olan Novoilinka 3 adlı arkeolojik alanda iki kez kazı çalışması yürütülmüș, 2004'teki araştırmada bulunan kemiklerin \%94'ünü, 2010'daki araştırmada bulunan kemiklerin ise \%96'sını at kemikleri oluşturmuştur. ${ }^{9}$ Söz konusu buluntular dikkate alındığında atla ilgili buluntuların Altaylarda M.Ö. III.-IV. bin yıllara kadar gittiğini görmekteyiz. Bu vesileyle de Afanasyevo dönemi, atın bozkır hayatında görüldüğ̈̈ ilk katmandır.

İlk dönemlere ait arkeolojik kazı alanlarında bulunan kemiklerin durumuna bakarak, beslenen atların genellikle yaşlı olmadığı tespit edilmiştir. Henüz ticaretin önem kazanmadığ ve daha çok avcılık yapılan bu ilk dönemlere ait kazı çalışmalarındaki buluntulara göre atların genellikle gıda maddesi olarak kullanıldığı anlaşılmakta olup, buluntular da bu durumu destekler niteliktedir. ${ }^{10} \mathrm{Bu}$ durum Altay, Kazakistan ve Moğolistan'daki Afanasyevo kültürüne ait kurganlarda görülmüştür. ${ }^{11}$ Bunun yanı sıra atların binek amaçlı kullanıldığına dair izler de tespit edilmiştir. ${ }^{12}$ Ayrıca bazı kurganlarda rastlanan araba kalıntıları göz önüne alındığında yük hayvanı olarak kullanıldığı sonucuna da varılabilir. Bu dönemde atların kızak çekmek için

${ }^{3}$ Bahaeddin Ögel, Islamiyetten Önce Türk kültür Tarihi, Türk Tarih Kurumu Basımevi, Ankara 1984, s.72; Kafesoğlu, "At", s.27.

${ }^{4}$ N.M. Yermolova, "K voprosu o Sibirskom Tsentre Odomaşnivaniya Loşadey" İzuçeniya po Mezolitu i Neolitu SSSR, Leningrad 1983, s. 188-191.

${ }_{5}$ Ye.A. Turina, "İstoriya İzuçeniya Hozyaysva Naseleniya Afanasyevskoy Kulturı", Hozyaysvenno-Kulturnıye Traditsii Altaya v Epohı Bronzl, Barnaul 2010, s.12-14.

${ }^{6}$ Yu.F. Kiryușin, Eneolit i Rannaya Bronza Yuga Zapadnoy Sibiri, Barnaul 2002, s.100.

${ }^{7}$ P.A. Kosintsev-N.F. Stepanova, "Fauna Afanasyevskogo Paselelniya Malıy Dugan", Afanasyevskiy Sbornik I, Barnaul, Azbuka 2010, s.124.

${ }^{8}$ P.İ. Şulga, “O Hozyaystve Afanayevtsev Gornogo Altaya”, Afanasyevskiy Sbornik II, Barnaul, Azbuka 2012, s.205.

${ }^{9}$ L.L. Gayduçenko-K.Yu. Kiryuşin, "Prigarı İz Keramiçeskih Sosudov Poseleniya Novoilinka-III v Severnoy Kulunde”, Arheologiya Zapadnoy Sibiri i Altaya: Optt Mejdistsiplinarnih Íccledovaniy, Barnaul 2015, s.106.

${ }^{10}$ N.A. Bokovenko-P.Ye. Mityayev, "Afanasyevskiy Mogilnik Malinoviy Log na Eniseye”, AfanasyevskiySbornik I, Barnaul, Azbuka 2010, s.16; P.İ. Şulga, "Noviye Materialı po Afanasyevskoy Kulture v Basseyne Çarışa", Severnaya Yevraziya v Epohu Bronzl: Prostranstvo, Vremya, Kultura, Barnaul 2002, s.150-154.

${ }_{11}$ V.A. Podobed-A.N. Usaçuk-V.V. Tsimidanov, "Tupiki v Kulturah Bronzovogo Veka”, Arheologiya Zapadnoy Sibiri i Altaya: Opıt Mejdistsiplinarnıh İccledovaniy, Barnaul 2015, s.255-256.

${ }^{12}$ Kiryuşin, Eneolit i Rannaya Bronza Yuga Zapadnoy Sibiri, s.101. 
kullanılmış olabileceği de düşünülmektedir. ${ }^{13}$ Kazılarda elde edilen kemik kalıntılarından yola çıkarak, bu kültür katmanında genellikle kısa boylu atların beslendiği tahmin edilmektedir. Kendi dönemindeki kaya resimlerine de bakarak, bu kültürün yetiştirdiği atların Moğol ve Yakut atlarına benzediği görülmüsstür. $\mathrm{Bu}$ at tipi Altaylarda demir çağının ilk dönemlerine kadar görülmüştür. ${ }^{14}$

Altaylarda Afanasyevo kültür tabakasının yerini M.Ö. 1700 - M.Ö. 800 yıllarında Andronovo kültürü almıştır. Andronovo kültüründeki atların durumu hakkında hem kurganlardan hem de diğer arkeolojik alanlar ve kayalar üzerine çizilen resimlerden bilgi edinmekteyiz. Bu dönemdeki kayalar üzerine çizilen resimlerde ve birtakım günlük eşyalarda atın ve at arabasının izleri görülmüştür. ${ }^{15}$ Kaya resimlerinde yer alan atlara koşulmuş savaş arabaları, ${ }^{16}$ Andronovo kültüründe atların savaşta da kullanılmaya başladığını gösterir.

$\mathrm{Bu}$ kültürün at arabalarına ait buluntular, kurgan ve yerleşim yeri kazılarında da tespit edilmiştir. Bununla birlikte at tiplerine dair veriler de vardır. Andronovolıların kendi arabaları için özenle eğittikleri büyük atlarının bulunduğu ve bunların 1,6 m boyunda oldukları hatta daha da boylu olabilecekleri rivayet edilir. Söz konusu atların Tunç çağındaki en boylu atlar olma ihtimali yüksektir. ${ }^{17}$ Bununla birlikte bu kültürde birden çok at tipi görülmektedir. ${ }^{18}$ At besiciliği konusunda ise hem yerleşim yeri kazıları hem de kurgan kazıları yeterince bilgi vermektedir. ${ }^{19} \mathrm{Bu}$ dönem kurganlarında ata ait uyluk kemiklerine, kaburga parçalarına, boynuna, kafatasına ${ }^{20}$ ve diğer birtakım kısımlarına rastlanmakla birlikte yaklaşık tamamının gömüldüğü kurgan örneği de mevcuttur. ${ }^{21}$ Atın bu şekilde kurganlara gömülmeye başlaması onun artık inanç sistemi içerisinde yer almaya başladığını ve manevi hayatın bir parçası haline dönüştüğünü göstermektedir.

Bu konuda Ye. Kuzmina'nın da kayıtları vardır. Ye. Kuzmina'nın kayıtlarına göre at, Andronovolıların inanç sistemine bağlı uygulamalarında önem arz etmekteydi. Ritüel uygulamalarda at postu kullanılmış, ${ }^{22}$ mezarlara da onun kafası ya da derisi gömülmüştür. ${ }^{23} \mathrm{Bu}$ bilgiler atın, toplum hayatındaki inanç sistemi içerisinde yer almaya başladığını ve atla ilgili çeşitli dini uygulamalar yapılmaya başlandığını göstermektedir.

İskit, Hun ve Göktürkler gibi Türk tarihi için önem arz eden dönemlerde ise gerek at ve ata ait eşyalar hakkında, gerekse atların inanç sistemi içerisindeki ve çeşitli dini uygulamalar çerçevesindeki durumları hakkında yeterince bilgi elde edilmektedir. Yukarıda aktardığımız bilgiler ise atın toplum hayatındaki ilk izleri ve daha sonrasında inanç sistemi içerisinde yer

\footnotetext{
${ }^{13}$ L.R. Kızlasov, “Afanasyevskaya Epoha v İstorii Hakasii”, Vestnik Moskovskogo Universiteta, Sayı 2, Moskova 1971, s.66-75; N.V. Leontyev, "Kolesniy Transport Epohi Bronzı na Yeniseye, Voprosı Arheologii Hakasii, Abakan 1980, s.65-84.

${ }^{14}$ Kiryuşin, Eneolit i Rannaya Bronza Yuga Zapadnoy Sibiri, s.101.

15 İ.V. Kovtun, "Nonfigurativnost Andronovskogo İskusstva: İdei, Fakt1, İnterpretatsii", İzvestiya Altayskogo Gosuderstvennogo Universiteta, Cilt 4, Say1 60, 2008, s.95-101; M.Ye. Kilunovskaya, "Noviye Petroglif1 na Yujnom Sklone Vostoçnogo Tannu-Ola v Tuve", Arheologiya Yujnoy Sibiri, Kemerova 2011, s.88.

${ }^{16}$ Ye.Ye. Kuzmina, Otkuda Prişli İndoarii, Moskova 1994, s.166.

${ }^{17}$ Kuzmina, a.g.e., s.164.

18 Saadettin Y. Gömeç, “Türk Kültüründe At”, Uluslararası Sempozyum: Geçmişten Günümüze Bozkır, Selçuk Üniversitesi Yayınları, Konya 2016, s.820.

19 G.A. Milyayev, "Model Jivotnovodstva Andronovskogo Obşestva po Materialam Poseleniy Vostoçnogo Kazahstana", Arheologiya Zapadnoy Sibiri i Altaya: Opıt Mejdistsiplinarnıh Íccledovaniy, Barnaul 2015, s.233-236.

${ }^{20}$ Yu.F. Kiryuşin-S.P. Gruşin, "Hozyaystvo Naseleniya Andronovskoy Kulturı Verhnego Priobya", HozyaysvennoKulturnıye Traditsii Altaya v Epohı Bronzı, Barnaul 2010, s.86-95.

${ }^{21}$ M.P. Gryaznov, “Andronovskaya Kultura I”, Arheologiya SSSR, Moskova-Leningrad 1966,s.6, 9, 39-40.

${ }^{22}$ Kuzmina, a.g.e., s.203.

${ }^{23}$ Kuzmina, a.g.e., s.166.
} 
alan uygulamalara dair ilk verileri içermektedir. Kültürün bir parçası olarak ve bir çeşit ritüel uygulama olarak değerlendirebileceğimiz atın kuyruğunun bağlanması ve bağlandığı yerden kesilmesi de bu ilk uygulamaların sonraki dönemlere olan yansıması olarak değerlendirilebilir. Atın kuyruğu ile ilgili uygulamalar konusundaki en eski bilgiler ise şimdilik M.Ö. V. yüzyıla kadar gitmektedir.

\section{2- İslamiyet'ten Önce Türk Kültüründe At Kuyruğu Bağlama ve Kesme Âdeti}

Savaşlarda ve ölüm durumunda atın kuyruğunun bağlanması ve bağlandığı yerden kesilmesi âdeti Türk kültür tarihinin çeşitli dönemlerinde karşımıza çıkmaktadır. Bu uygulamayla ilgili en eski örnekleri ise kurganlarda bulunan atların durumlarıyla ilgili verilerde ve yine kurganlarda bulunan çeşitli eşyalar üzerindeki figürlerde görmekteyiz.

Altay bölgesinde kazılan M.Ö. V.-VI. yüzyıllara ait çeşitli kurganlarda atın kuyruğunun bağlandığı ve

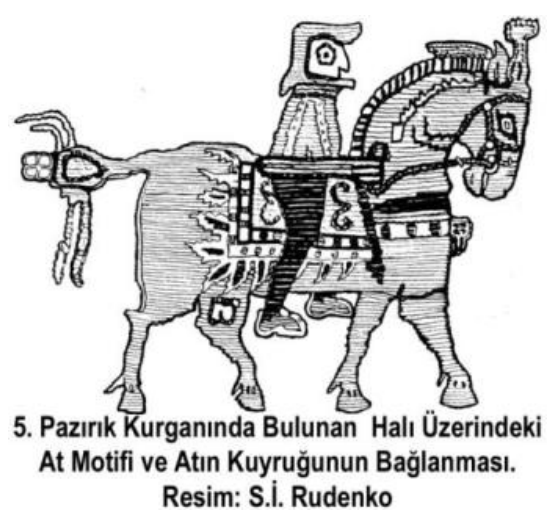

Volume 12

kesildiğine dair açık ve net veriler içeren bulgular elde edilmiştir. Bu kurganlardan birisi, maddi kültür tarihi açısından oldukça önemli olan Pazırık kurgan grubudur.

M.Ö. IV.-V. yüzyıllara ait olduğu ${ }^{24}$ kaydedilen İkinci Pazırık kurganında kafaları doğu istikametine çevrilmiş yedi tane at bulunmuştur. Atların hepsinin kuyruğu ve yeleleri siyah renkte idi. İkisi hariç diğerlerinin yeleleri kesilmişti. 6 tanesinin kuyrukları örülerek üç kuşaklı bir melik haline getirilmiş, birisinin kuyruğu ise iç içe kıvrılmak suretiyle daire şeklinde toplanmıştı. Kuyrukların uçları ise toplanarak bağlanmıştı. ${ }^{25}$

Beşinci Pazırık kurganında ise 9 adet at tespit edilmiştir. Bu atların tamamında yeleler kısaltılmış uçlarından kesilmişti, kuyrukları ise uçlarından kesilmiş geri kalanı da örülerek üç kuşaklı bir melik haline getirilmişti. Kuyrukların orta kısmında altın plakalı deri örtüler yer almaktaydı. Beşinci Pazırık kurganında bulunan bir halı da üzerindeki desenler ve bu desenlerin konumuzla olan bağlantısı açısından oldukça ilgi çekicidir. Kurgandaki halı ahşaptan yapılmış dört tekerlekli bir at arabasının üzerine örtülmüştü. Halı dikdörtgen şeklindeydi ve ölçüleri 1,83 x 2 m büyüklüğünde idi. ${ }^{26}$ Halının üzerinde geyik, yaprak ve çeşitli motifler olmakla birlikte dış kenarlarına yakın yerde bulunan atlı binici motifleri oldukça değerli bilgiler verir. Halının her bir kenarında yedi tane atlı binici figürü vardı, dolayısıyla dört kenarındaki toplam atlı binici figürünün sayısı 28 tane idi. Bu figürlere göre; atın yeleleri kısaltılmış, uçlarından kesilmişti, yeleler adeta düzgün bir şekilde üst kısmından tıraş edilmiş gibiydi. Bu durum yalnız figürde değil gerçeğinde de böyleydi, zira yukarıda bahsettiğimiz Pazırık kurganlarına gömülmüş olan atların yeleleri de bulundukları zaman tam olarak bu şekildeydi. Bu atlı binici figürlerindeki daha önemli nokta ise atların kuyruklarıyla ilgili meseledir. Atlı binici figürlerindeki atların tamamının kuyrukları aynı şekilde bağlanarak bir düğüm haline getirilmişti. Nitekim Beşinci Pazırık kurganında, kurgan odasına gömülen gerçek atların kuyruklarının örülerek melik haline getirildiği, halı motiflerindeki atların kuyruklarının ise bağlanarak bir düğüm halinde işlendiğini görmekteyiz.

\footnotetext{
${ }^{24}$ S.İ. Rudenko, Vtoroy Pazırıkskiy Kurgan, Leningrad 1948, s.59-60.

${ }^{25}$ Rudenko, Vtoroy Pazırıkskiy Kurgan, s.10-11.

${ }^{26}$ S.İ. Rudenko, Pyatıy Pazırıkskiy Kurgan, Moskova-Leningrad 1951, s.110-114.
} 
Günümüz Altay Özerk Cumhuriyeti'nin güneyinde bulunan Ukok platosundaki Ak Alaha kurganları da bulunan materyallerin zenginliği açısından kayda değerdir. Bu kurganlarda bulunan atlar, koşumları ve süs eşyaları bakımından oldukça zengindir. Bununla birlikte atların yeleleri ve kuyrukları da Pazırık kurganlarındaki atların durumuna çok benzemektedir. Ak Alaha kurganlarında yer alan atların kuyrukları örülerek uç kısımlarından bağlanmış, yeleleri de üst kısmından kesilerek kısaltılmıştır. ${ }^{27} \mathrm{Bu}$ durum Altay'da milattan önceki dönemlerden itibaren kazısı yapılan kurganlarda bulunan atların durumunda, çeşitli resimlerde, halılar üzerindeki figürlerde veya süs eşyalarının üzerine resmedilen figürlerde görülmektedir. Arkeologlar İskit döneminden itibaren kurgana konulacak atın daha kurban edilmeden önce kuyruklarının kesildiğini daha sonra kurban edilerek kurgana konulduğunu kaydetmektedir. ${ }^{28}$

Kazakistan'ın doğusundaki Esik kasabası yakınlarında, tunçtan yapılmış ve kandil olduğu tahmin edilen, ayaklı tabak şeklinde bir kap bulunmuştur. İskit dönemine ait olduğu kaydedilen bu eser, dairesel ayak üzerine oturtulmuş bir tabaktan oluşmaktadır. Tabak şeklindeki kabın üzerinde ise karşı karşıya duran bir insan ve bir at heykeli yerleştirilmiştir. İnsan heykeli diz çökmüş̧ vaziyette oturmuş, sol elini sol dizi üzerine koymuş ve sağ eliyle de bir çanak tutmuştur. Sağ elindeki çanağın, içine fitil yerleştirilen yağ kab1 olduğu düşünülmektedir. Karşısında duran at eyersizdir ancak gem vurulmuştur. Kafasının üzerindeki bir tutam kıl dışında yelesi görülmemektedir. Atın en dikkat çeken yeri ise kuyruğunun düğümlenmiş olmasıdır. ${ }^{29}$

Kazakistan'da yer alan Berel kurganları da atlar ve atlara ait çeşitli eşyalar yönünden zengindir. Berel kurganlarının birisinde 17, diğerinde 13, bir diğerinde ise 10 adet at tespit edilmiştir. Kurgan kazıldığ 1 sırada atlar

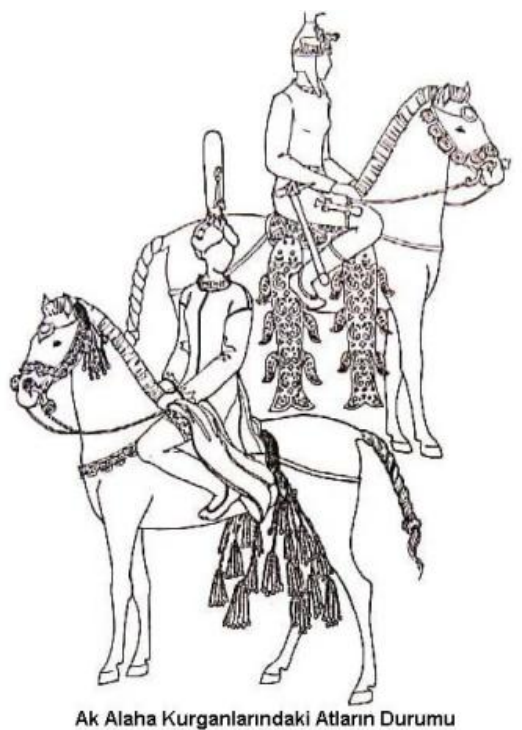

Ak Alaha Kurganlarındaki Atların Durumu
Resim: N.V. Polosmak

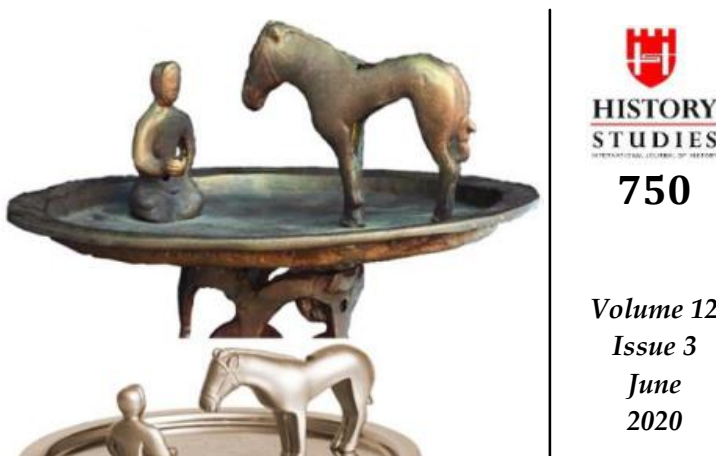
çürümüş geriye sadece iskeletleri kalmıştı. Bundan dolayı atlara bakarak kuyruklarının durumu hakkında yeterince bilgi elde edilememiştir. Ancak atların yanında bulunan eşyalar, atın kuyruğu ile ilgili yapılan uygulamalar hakkında bilgi vermektedir. Bu kurganlarda atla birlikte; at maskeleri, atın göğsünden geçirilen kemer, kuyruk örtüsü ve at figürü içeren eşya bulunmuştur. $\mathrm{Bu}$ sonuncu eşyadaki at figüründe dikkat çeken ayrıntı ise atın yelesinin ve kuyruğunun kesilmiş olmasıdır. Bu figüre bakarak Berel kurganlarına gömülen atların kuyruklarının yas âdeti olarak kesilmiş olduğunu veya at kuyruğunun kesilmesi geleneğine bağlı olarak yapılan yas âdetinin burada da mevcut olduğunu görmekteyiz. Berel kurganlarını inceleyen Kazak arkeolog Z. Samaşev, bu kurganların M.Ö. IV.-III. yüzyıllara ait olduğunu

${ }^{27}$ N.V. Polosmak, Vsadniki Ukoka, Novosibirsk 2001, s.278.

28 A.A. Tişkin, P.K. Daşkovskiy, Sotsialnaya Struktura i Sistema Mirovozreniy Naseleniya Altaya Skifskoy Epohi, Barnaul 2003, s.257.

${ }^{29}$ M.İ. Artamonov, Sokrovişa Sakov, Moskova 1973, s.40,44. 
kaydetmektedir. ${ }^{30}$ B. Ögel de bu kurganların Hun dönemine ve Hun kültürüne ait olduğunu ifade etmektedir. ${ }^{31}$ Hunlarda atın kuyruğunun bağlanması meselesine E. Esin de değinmektedir. E. Esin, Hiung-nularla (Hunlar) olan muharebeleri gösteren Çin taş oymalarındaki atların kuyruklarının bağlı olduğunu kaydeder, ayrıca muharebe ve av için kullanılan atların kuyruklarının bağlandığını dile getirir. ${ }^{32} \mathrm{Bu}$ bilgiler ışında at kuyruğu bağlama geleneğinin varlığı Asya Hunlarında da görülmektedir.

Macaristan'ın güneyindeki Segedin şehri yakınlarında bulunan Saint-Mikloş hazinesi maddi kültür tarihi açısından oldukça önemlidir. Bu hazinenin içerisinde yer alan, üzerinde Türkçe yazının da bulunduğu altın bir kaba işlenmiş kabartma hem savaş sırasındaki Türk atlı süvarisi hakkında hem de at kuyruğunun bağlanması hakkında oldukça değerli bilgi vermektedir. 1799 yılında keşfedilen bu hazinenin V.-VIII. yüzyıllara ait olduğu düşünülmektedir. Arkeologlar bulunan hazinenin ilk başta Avrupa Hunlarına ait olduğunu kaydetmişler ancak daha sonra Bulgar Türklerine ait oldukları yönünde fikirler de öne sürmüşlerdir. Bununla birlikte bu eserin Avarlara veya Hazarlara ait olabileceği yönünde de bilgiler

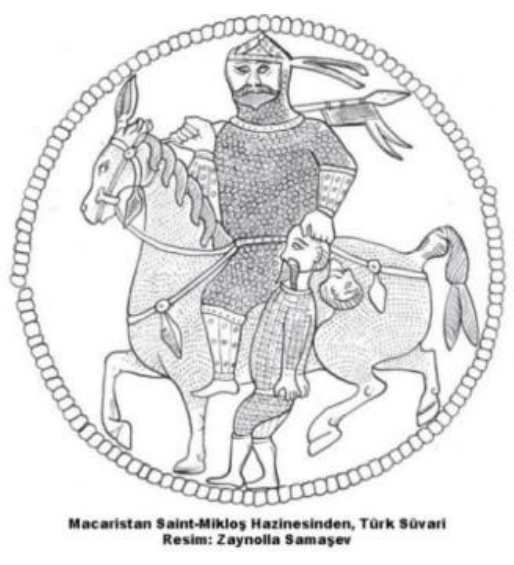
bulunmaktadır. Söz konusu altın kap üzerindeki kabartmada bir atlı süvari, öldürdügü bir düşmanın kafasını eyerine asmış, başka bir düşmanını da kafasından tutarak eyer boyuna kadar kaldırmıştır. Atlı süvarinin üzerinde zırhı ve diğer elinde de silahı yer almaktadır. Bindiği atın kuyruğu bağlanmış ve kuyruğun uç kısmı ikiye ayrılmıştır. ${ }^{33}$ Bu kabartma, Türk kültüründeki at kuyruğu bağlama âdetinin Türklerle birlikte Avrupa' ya taşındığını da göstermektedir. Böylece at kuyruğu bağlama geleneğinin Avrupa Hunlarında ve ardından Bulgarlarda da devam ettiğini görmekteyiz.

Atların kuyruğunun bağlanması ve kesilmesiyle ilgili uygulamalar Göktürklerde de devam etmiştir. Kazak Arkeolog Z. Samaşev, kaya resimleriyle ilgili bir çalışma yapmış ve Göktürk dönemine ait kaya resimlerini Eski Türk Grafikleri adlı kitabında toplamıştır. Bu kitapta çeşitli şekillere ait figürler olmakla birlikte süvarilerin ve atların durumunu betimleyen figürler konumuz açısından dikkat çekmektedir. Bu figürler incelendiğinde atların gerek savaş esnasında dörtnala koşar vaziyetteki durumlarında, gerekse üzerinde süvariyle birlikte veya yalnız olarak resmedildiği çeşitli figürlerde kuyruklarının bağlanmış olduğunu görmekteyiz. Bu figürler içinde bir tanesi oldukça dikkat çekmektedir ki, söz konusu figürde dörtnala koşan bir atın üzerinde yayını çekerek geriye doğru dönüp ok atan bir Türk süvarisi görülmektedir ve binmiş olduğu atın kuyruğu bağlanmıştır. Bir başka figürde yine süvari ve at birlikte resmedilmiştir. Üzerinde silahları bulunan bir süvari dört nala giden bir ata binmiş ve atın kuyruğu diğerinde olduğu gibi bağlanmıştır. Başka bir figürde ise yine bir süvari ve atı birlikte görmekteyiz. Ancak bu son figürde yürür vaziyetteki bir at üzerinde Türk süvarisi ve süvarinin elinde de öldürdüğü düşmanını görmekteyiz.

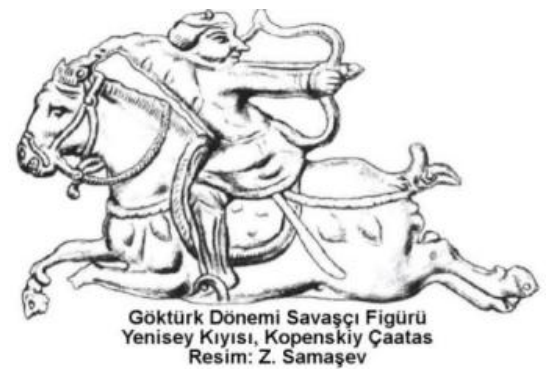

\footnotetext{
${ }^{30}$ Zaynolla Samaşev, "Kon v Ritualno-Obradovoy Praktike u Drevnego Naseleniya Kazahskogo Altaya”, Türik Düniyesi, Almatı 2013, s.616-625.

${ }^{31}$ Ögel, İslamiyetten Önce Türk kültür Tarihi, s.72.

${ }^{32}$ Emel Esin, Türklerde Maddi Kültürün Oluşumu, Kabalcı Yayınevi, İstanbul 2006, s.272.

${ }^{33}$ Zaynolla Samaşev, Drevneturkskaya Grafika, Astana 2013, s.160-161.
} 
Diğerlerinde olduğu gibi bu figürde de atın kuyruğu bağlanmıştır. $\mathrm{Bu}$ bilgileri kaydeden $\mathrm{Z}$. Samaşev, Göktürklerde at kuyruğu bağlanması âdetinin, genel olarak hanedan mensuplarında görüldügünü eklemektedir. $^{34}$

Göktürklerden sonra kurulan ve Türkistan'ın önemli Türk Devletlerinden birisi olan Uygur Türklerinde de aynı gelenek devam etmiştir. Yerleşik hayata geçen Uygurlar kendinden önceki Türk devletlerine göre yazı ve resim sanatını daha fazla kullanmışlar ve kültürlerini yansıtan çeşitli resimler, figürler, freskler çizmişlerdir. Bu resim sanatları içerisinde çalışmamız açısından dikkat çeken detaylardan birisi, kuyruğu bağlanmış olan atların varlığıdır. Uygur Türklerine ait bir resimde siyah renkteki bir at dörtnala koşar vaziyette çizilmiştir, üzerinde binicisi olmayan bu atın kuyruğu bağlanmıştır. ${ }^{35}$ Uygur dönemine ait binici detaylı bir başka resim de Hotan'da

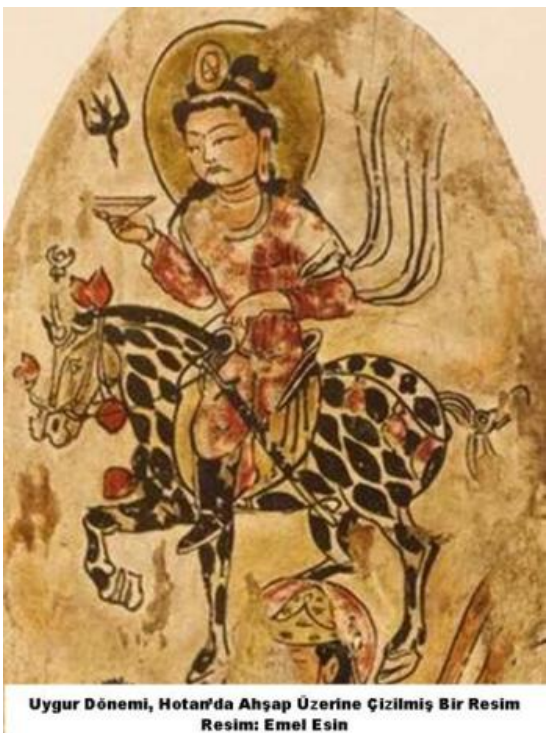
Resim: Emel Esin bulunmuştur. Bu resmin VIII.-IX. yüzyıllara ait olduğu düşünülmektedir. Bir ahşap üzerine çizilen bu resimde, saçları uzun, elinde kupa tutan ve belinde kılıç asılı bir süvari figürü vardır. Binmiş olduğu atın kuyruğu diğerlerinde olduğu gibi düğümlenmiştir. ${ }^{36}$

Atların kuyruğuyla ilgili âdetleri Oğuzlarda da görmekteyiz. Bulgarlara giderken Oğuz ülkesinden geçen İbn Fadlan'ın aktardığı bilgilere göre Oğuzlar, önemli bir kişi öldüğünde onun hayvanlarından bir kısmını öldürürler ve bu hayvanların kuyruğunu, başını, derisini ve ayaklarını bir sırığa geçirerek mezarının başına dikerlerdi. ${ }^{37} \mathrm{Bu}$ bilgiden yola çıkarak atın kuyruğunun yas alameti olarak kesilmesi âdetine Oğuzlarda da rastlandığı sonucuna varabiliriz. Burada at kuyruğunun doğrudan mezar üzerine dikilmesi âdetine rastlamaktayız. B. Ögel, at kuyruğunun ölen yiğidin mezarı üzerine asılmasının bir yiğitlik ve savaş sembolü olduğunu belirtmektedir. $^{38}$

Dede Korkut'ta yer alan Beyrek'in hikayesindeki, Beyrek öldüğü zaman, Ak-boz atının kuyruğunu kestiler deniyordu. Yani er kişinin at1, onun çok yakın bir eşi olarak görülmüştür. Ölen kişiye ait atın kuyruğunun kesilmesine ise dullama (tullamak) deniyordu. Sahibi öldüğü zaman at da onun eşi gibi dul kalıyor ve bu da kuyruğunun kesilmesi vasıtasılyla sembolleştirilmiş oluyordu. ${ }^{39}$ Savaşa girecek er de atının kuyruğunu bağlar veya keserdi ve buna da tullama denirdi. Artık o kişi, vatan ve millet için kendini fedaya ve şehitliğe hazırlamış demekti. ${ }^{40}$

Atın dul kalması şeklindeki düşünce Kazaklarda da yakın zamana kadar sürmüştür. Kazaklarda da ölenin yedisindeki yemeğin ardından, onun hayattayken bindiği at veya atlardan bir-ikisinin kuyruk ve yeleleri kesilirdi. Bu atın eyeri ters çevrilir, üstüne de ölenin elbisesi ve malakay şapkası konur, ölünün bulunduğu çadırın önüne getirilip bağlanırdı. Kazaklar bu uygulamaya dul bırakmak anlamında tuldav derlerdi. Atın kuyruğunu kesmek ise ölümü

\footnotetext{
${ }^{34}$ Samaşev, Drevneturkskaya Grafika, s.109, 120, 160, 257.

${ }^{35}$ Emel Esin, "The Horse in Tukic Art”, Central Asiatic Journal, Vol. 10, No. 3/4, 1964.

${ }^{36}$ Esin, Türklerde Maddi Kültürün Oluşumu, s.274.

${ }^{37}$ Ramazan Şeşen, İbn Fadlan Seyahatnamesi, Yeditepe Yayınları, İstanbul 2019, s.15.

${ }^{38}$ Bahaeddin Ögel, Türk Kültür Tarihine Giriş VI, T.C. Kültür Bakanlı̆̆ı Yayınları, Ankara 2000, s.197.

${ }^{39}$ Ögel, Türk Kültür Tarihine Giriş VI, s.199-200.

${ }^{40}$ Gömeç, agm, s.830.
} 
çağırmak ve ölüme davet çıkarmak anlamına geldiğinden, atın kuyruğunun nedensiz yere kesilmesi yasaklanmıştır. Nedensiz yere at kuyruğu kesenler de şiddetle cezalandırılmıştır. Dul bırakılan bu ata binilmesi de yasaklanmıştır. ${ }^{41}$

Tanrı dağlarındaki Kırgız Türkleri, ölen kişinin mezarı üzerine bir sırık dikiyorlar ve ölenin atının kuyruğunu bu sırık üzerine bağlıyorlardı. Bu uygulama aynı zamanda Türklerdeki tuğ geleneği hakkında da bilgi vermektedir. ${ }^{42}$

\section{3- İslamiyet’ten Sonra Türk Külttüründe At Kuyruğu Bağlama ve Kesme Âdeti:}

Türk tarihi kendi içerisinde siyasi ve kültürel bakımdan bütünlük ve süreklilik göstermektedir. Nitekim İslâmiyet öncesi Türkler arasında görülen adetlerin ve uygulamaların sonraki devirlerde de devam ettiği görülmektedir. Bu minvalde atların kuyruğunun bağlanması ve kesilmesiyle ilgili uygulamalar Büyük Selçuklu Devleti zamanında da görülmüştür. Zira İslam öncesi Türk topluluklarında görülen yuğ/yoğ gelenekleri, halkının büyük bir kısmı İslamiyet'i kabul etmiş olmasına rağmen Selçuklular döneminde de devam etmiştir. Türklerin İslamiyet'i seçmeden önceki kültürlerinde mevcut olan "yuğ adetleri” ile alakalı İ. Kafesoğlu, şöyle demektedir:

“Eski Türklerde ölüm hâlinde yas törenleri yapılır, kırlarda ise, ölünün bulunduğu çadır etrafinda sür'atli atlarla dolaşılır, saçlar kesilir, saç-baş dağıtılır, yüz, kulak bıçakla çizilerek kan akıtılır, ölenin atları,

kuyrukları kesilerek kurban edilir, ayrıca yemek verilirdi. ",43

Kafesoğlu'nun yaptığı bu tarif ile Büyük Selçuklu Devleti'nin kontrolündeki topraklarda görebildiğimiz ölen kişinin ardından yapılan bazı gelenek, uygulama ve davranışlar önemli ölçüde benzerlik göstermekle ${ }^{44}$ birlikte Büyük Selçuklu devrinde hanedana mensup kişilerle halktan birisinin ölümünden sonra yas tutma geleneklerinde zaman zaman birtakım farkl11ıklar görülebilmektedir. Ancak farklılıklara oranla benzerlikler daha fazladır ve bunlar Selçuklular zamanındaki taziye merasimleri, her ölümden sonra tertip edilen tek müşterek faaliyet olarak karşımıza çıkmaktadır. Selçuklular zamanında sultan, vezir, hanedan üyeleri, din adamı veyahut halkın arasından bir kimse için cenaze törenleri düzenlenmekteydi. Çalışmamızın konusunu oluşturan at kuyruğu bağlama ve kesme âdeti ile taziye merasimlerini, önceki dönemlerde olduğu gibi Selçuklularda da bir arada görmekteyiz. ${ }^{45}$

Bu uygulamanın bir örneğini de Büyük Selçuklu Devleti Sultan'1 Tuğrul Bey'in (10401063) ölümünden sonra görmekteyiz. Sultanın, Rey şehrinde öldüğü halk tarafından duyulduğu zaman kimi emîr ve saray mensupları İslamiyet öncesi Türk örf ve adetleri icabınca kıyafetlerini yırtmak istemiş fakat vezir Amîdülmülk böyle işlerle meşgul olmanın vakit kaybına sebep olacağını söyleyerek bu tarz hareketleri engellemiştir. Bu olaylar yaşanırken Amîdülmülk'ün Sultanın veliahdı Süleyman'ı tahta oturtmasına, Alp Arslan'ın destekçileri tepki göstermiş ve yaşanan kargaşa ortamından dolayı Selçuklu hanedanına mensup herkes için düzenlenen taziye Rey'de Tuğrul Bey adına düzenlenememiştir. Bu mesele ile ilgili Osman Turan şöyle demektedir:

\footnotetext{
${ }^{41}$ Fatih Ünal, “Kazak Türklerinde Defin Merasimi ve Aş Verme Geleneği”, Bilig, Sayı 45, Bahar 2008, s.115.

${ }^{42}$ Ögel, Türk Kültür Tarihine Giriş VI, s.199-200.

${ }^{43}$ İbrahim Kafesoğlu, Türk Millî Kültürü, Ötüken Yayınları, İstanbul 1998, s.303.

${ }^{44}$ A.g.e., s.303.

${ }^{45}$ Cihan Piyadeoğlu, "Büyük Selçuklular Dünyasında Yas Tutma Âdetleri ve Taziye Üzerine Merasimler”, Trakya Üniversitesi Edebiyat Fakültesi Dergisi, c.2, say1.3, Ocak-2012, s.29.30.
} 
“Vezir Amîdülmülk askerlerin matem yapmalarına ve Türk mâtem (yuğ) an'anesine göre elbiselerini yırtmalarına müsaade etmedi fakat halîfe ve veziri ${ }^{46}$ Bağdad'da Sultan için resmî matem ilân ederek taziyeleri kabul etti."

Bazı kaynaklarda ise Sultan Tuğrul Bey için tertip edilen yas törenine gelenlerin atlarının kuyruklarının kesik olduğu aktarılmaktadır. ${ }^{47}$ Sultan Alp Arslan (1063-1072) devrinde de atların kuyruğunun bağlanması veya düğümlenmesi âdeti devam etmiştir. 27 Zilkade 463/26 Ağustos 1071 Cuma günü Büyük Selçuklu Devleti ile Bizans İmparatorluğu arasında yapılan Malazgirt savaşında öğlene kadar askerlerin savaş düzeni ile ilgilenen Sultan Alp Arslan, ordusundaki askerler ile beraber Cuma namazını kıldıktan sonra onlara şu şekilde hitap etmişti:

\begin{abstract}
“Askerlerim! Sayıca az olmamıza rağmen ben düşmana, minberlerde bizim için ve Müslümanlar için dua edilmekte olan bu saatte saldırmak istiyorum. Ya amacıma ulaşır ya da şehit olarak cennete giderim. Sizlerden benim arkamdan gelmek isteyenler gelsin, istemeyenler ise geri dönüp gidebilir. Şimdi burada ne emreden bir sultan ne de emir alan bir asker vardır. Bugün, burada bende sizlerden biriyim ve sizinle birlikte savaşacağım. Beni izleyen ve canını yüce Allah'a adayan kimse cennete gideceği gibi ganimete de sahip olacaktır. Benden uzaklaşıp gidenler ise ateşte yanacak ve kötülüklere uğrayacaktır”.
\end{abstract}

Sultanının bu etkili konuşmasına karşılık olarak askerler de: "Ey Sultan! Biz senin kullarınız. Sen ne yaparsan biz de aynisını yaparız ve sana yardımcı oluruz Sen istediğin gibi hareket et”. demişlerdir. Sultan Alp Arslan askerlerin bu cevabından sonra, okunu ve yayını atıp, kılıç ve topuzunu aldı. Ayrıca atının kuyruğunu bizzat eliyle bağladı ${ }^{48}$ ve askerleri de aynı şeyi yaptılar. Daha sonra ak elbise giyip güzel kokular süründü ve: "Ölürsem kefenim budur" dedi. Ardından da düşmana saldırdı ve askerleri de Sultan Alp Arslan’ı takip ettiler. ${ }^{49}$

${ }^{46}$ Abbasilerin veziri Fahrüddevle İbn Cehir Sahnü’s-Selâm'da 26 Ramazan455/22 Eylül 1063tarihinde Tuğrul Bey adına bir taziye merasimi düzenlemiştir. Bkz. Sıbt İbnü'l-Cezvî, Mir'âtü'z-zamân Fî tarihi'l- 'Âyân, çev. Ali Sevim, Makaleler II, Berikan Yayınları, Ankara 2005, s.180-181-183.

${ }^{47}$ İbnü'l-Esîr, el-Kâmil fi 't-tarih, çev. Abdülkerim Özaydın, Bahar Yayınları, İstanbul 1991, c.X, s.41-42; İbn Kesîr, el-Bidâye ve'n-nihâye, çev. Mehmet Keskin, İstanbul 1995, XII, 203; el-Feth b. Ali b. Muhammed el-Bundârî, Zübdetü'n-nusra ve Nuhbetü'l-usra, çev. Kıvameddin Burslan, Irak ve Horasan Selçukluları Tarihi, TTK Yayınları, Ankara 1999, s. 24, 25, 26; Hamdullah Müstevfî-yi Kazvinî, Târih-i Güzide, çev: Mürsel Öztürk, TTK Yayınları, Ankara 2018, s 343; Ahmed b. Mahmûd, Selçuk-Nâme, haz. Erdoğan Merçil, İstanbul 1977, I, s.49-50; Osman Turan, Selçuklular Tarihi ve Türk-İslâm Medeniyeti, Turan Neşriyat Yurdu, İstanbul 1969, s.102; Mehmet Ali Hacıgökmen, "Türklerde Yas Âdeti Temelleri ve Sonuçları", Tarihçiliğe Adanmış Bir Ömür Prof. Dr. Nejat Göyünç'e Armağan, Konya 2013, Selçuk Üniversitesi Türkiyat Araştırmaları Enstitüsü Yay, s.407; Mehmet Altay Köymen, Tuğrul Bey ve Zamanı, Kültür Bakanlığı Yayınları, İstanbul 1976, s.142-143; Sibti̇bnü’l-Cevzî, a.g.e., 513-514; Doğan Kaya, Anonim Halk Şiiri, Akçă̆ Yayınları, Ankara 1999, s.251.

${ }^{48}$ At kuyruğu bağlamayla ilgili, bu adet Türk kültüründe genellikle yas ve matem merasimlerinde kuyruk kesme, düğümleme, örme veya bağlama şeklinde gerçekleşmiştir. Bazen de Malazgirt savaşında olduğu gibi adanmışlık veyahut uzun olan atkuyruğunun savaş esnasında atın ayaklarına veya başka bir yerine dolanmasını önlemek maksadıyla gerçekleştirilirdi. Eski Türkler'de "kuyruk tügmek" ya da "at çermetmek" denilen bu işlem sırasında ipek sicimler kullanılmaktaydı, bkz. Salim Koca, Selçuklular'da Ordu ve Askeri Kültür, Berikan Yayınevi, Ankara 2005, s. 204-205; Atın kuyruğunu bağlamak çok eski bir Türk geleneğidir. Türkler, yapacakları bir seferden ve girişecekleri bir savaştan geri dönmemek ve bu teşebbüslerinde mutlaka bir başarıya ulaşmak için atlarının kuyruklarını bağlarlardı. Bu hususta bkz. Faruk Sümer, Oğuzlar (Türkmenler) Tarihleri-Boy Teşkilâtı-Destanları, Ankara Üniversitesi Dil ve Tarih-Coğrafya Fakültesi Yayınları, Ankara 1972, a.415-416;

${ }^{49}$ Malazgirt savaşı hakkında bkz. Urfalı Mateos, Vekayi-Nâme (952-1136) ve Papaz Grigor'un Zeyli (1136-1162), (Çev. Hrant D. Andreasyan), TTK Yayınları, Ankara 2000, s. 143; İbnü'l Esîr, X, s.72; Ahmed b. Mahmûd, I, s. 99100; Sadreddîn el-Hüseynî, Ahbârü'd-Devleti's-Selcukiyye (Zübdetü't-tevârih), çev. Necati Lugal, TTK Yayınları, Ankara 1999, s.33-35; Faruk Sümer-Ali Sevim, İslam Kaynaklarına Göre Malazgirt Savaşı (Metinler ve Çevirileri), TTK Yayınları, Ankara 1971, s.9-14-21-25; Ali Sevim, “İbnü'l-Kalânisî'nin Zeylü Tarih-i Dımaşk Adlı Eserinde Selçuklularla İlgili Bilgiler I. (H. 436-500-1044/45-1106/07)", TTK Belgeler, Cilt XXIX, Sayı 33, 2008, s. 8; Ali Sevim-Erdoğan Merçil, Selçuklu Devletleri Tarihi, TTK Yayınları, Ankara 1995, s 67; Ali Sevim, Malazgirt Meydan Savaşı, TTK Yayınları, Ankara 1971, s.77; aynı müellif, "Malazgirt Muharebesi”, DİA, c. XXVII, Ankara 2003, s.481-483; Cihan Piyadeoğlu, Sultan Alp Arslan Fethin Babası, Kronik Yayıncılık, İstanbul 2016, s. 192; Reşîüddîn Fazlullah, Câmiu't-tevârîh, çev. E. Göksu-H. H. Güneş, Selenge Yayınları, İstanbul 2010, s.113. 
Selçuklularda atların kuyruğunun bağlanması ve kesilmesiyle ilgili uygulamalar Sultan Melikşâh (1072-1092) zamanında da görülmektedir. Melikşâh'ın Karahanlllar soyundan olan eşi Terken Hatun'dan dünyaya gelen oğlu Davud'un vefatı sebebiyle yapılan matem hakkında dönem kaynakları önemli bilgiler aktarmaktadırlar. Kaynaklarda geçen bilgilere göre Sultan, 12 Mayıs 1082 yılında İsfahan'da oğlu Davud'un vefatına çok üzülmüş ve hatta bir kaç defa intihara teşebbüs etmiş, ancak yanındakiler ona engel olmuş ve onu biran bile yalnız bırakmamışlardı. Zira Melikşâh'ın takati ve dayanacak gücü kalmamıştı. Sultan, hep oğlunu kokluyor ve cenazesinin yıkanmasına mani oluyordu. Ayrıca yemeden içmeden kesilmiş ve bunun sonucunda da bitap düşmüştü. Bu sebeple giysilerini çekiştirip durmuş ve teselli edenlerden uzaklaşmıştı. Türkmenler ise Saltanat Sarayı'nda bir araya gelip saçlarını, başlarını yolmuş, saraydaki kadınlar, hizmetçiler, hekimler ve hâdimler de onlara katılmışlardı. Ayrıca atlarının alınlarındaki kâkülleri kestiler, eyerlerini ters çevirdiler ve üzerlerine karalar sürdüler. Melikşâh'ın yasına bütün halk katılmış ve bu durum bir hafta boyunca devam ettirilmiştir. Davud öldükten bir ay sonra Sultan Melikşâh ava çıkmış ve şu mektubu yazmıştır;

\begin{abstract}
"Ey oğlum Davut! Sensiz ava çıktım, senden ayrılmanın bana verdiği sıkıntı ve senden uzak kalmanın getirdiği yalnızlık içindeyim. Felek seni benden aldı̆̆ı, gecelerimi uykusuz kıldığı, hayatımı berbat ettiği, ciğerimi parçalayıp üzüntümü artırdı̆̆ i için ağllyorum. Hadi, bana bildir bakalım, benden ayrıldıktan sonra durumun nasıldır? Ölüm, seni değiştirdi mi? Mezar kurtlart sana ve vücuduna ne yaptı? Toprak, yüzüne ve gözlerine ne yaptı? Sen de benim gibi misin? Benim kadar üzüntülü müsün? Seni ne kadar çok özlüyorum, senin için ne kadar çok üzülüyorum. Vah senin yokluğuna vah!"
\end{abstract}

Melikşâh'ın oğlu Davud için yazdığı bu kâğıt parçası Nizâmülmülk'e götürülüp verildiği zaman Nizâmülmülk hüngür hüngür ağlayıp, ileri gelen devlet erkânıyla beraber Davud'un mezarına giderek bu mektubu mezarı başında okudu. Davud'un mezarı başındakilerinin ağıt, feryat ve figanları her tarafı sardı, ülkede matem tazelendi. Sultan Melikşâh'ın yaşadığı diğer

Volume 12

Issue 3

June

2020 bir üzüntülü hadise de Veliaht Ahmed'in 481/1088-1089 yılında, Merv'de henüz 11 yaşındayken ölmesidir. Bu hadisede de yine yas töreni yapılmıştı. Fakat bu seferki matemde at kuyruğu, bağlama veya kesmeden farklı olarak Ahmed'in vefatıyla beraber matem icabınca hiç kimse ata binmemiştir. Halk bilhassa da kadınlar ağıt yakmış ve feryat-figan etmişlerdi. ${ }^{50}$

Daha önce de izah ettiğimiz gibi bu matem gelenekleri ve törenleri vezirler ve aileleri için de yapılmaktaydı. Büyük Selçuklu Devleti’nin bilge veziri Nizâmülmülk’ün oğluna ve kızına yas merasimleri tertip edilmiştir. Cemâlülmülk, Melikşâh'ın maskarasını babasının komik taklitlerini yapması sebebiyle infaz etmişti. Bu meseleye çok kızan Sultan'da Nizâmülmülk'ün oğlunu Recep 475/Kasım-Aralık 1082 senesinde öldürtmüştü. Cemâlülmülk’ün öldürülmesinden sonra annesi, yakınları ve gulâmları saçlarını yolmuş, atların yeleleri kesilmiş, ayrıca bunlar cenazenin bulunduğu çadırın önüne serpilmiştir. ${ }^{51}$

\footnotetext{
${ }^{50}$ İbnü'l-Esîr, X, s.116-117; İbn Kesîr, XII, s.251-252; İbnü'l-Cevzî, a.g.e., s.562-563; Ahmed b. Mahmûd, I, s. 139140; Sıbti̇bnü'l-Cevzî, a.g.e., s. 375-376; Sevim-Merçil, Selçuklu Devletleri, s. 116.

51 İbnü'l-Esîr, X, s.118-119; Sibtİbnü'l-Cevzî, a.g.e., s.384-385; İbrahim Kafesoğlu, Büyük Selçuklu İmparatoru Sultan Melikşah, MEB, İstanbul 1973, s. 179-180; Cemalülmülk, Nizamülmülk'ün büyük oğlu olup, daha, cür'et, izzeti nefis ve nahvet sahibi idi. Alp Arslan zamanında, babası buna, Alp Arslan'ınoğlu Melikşah'a, vezir olmayı teklif etti. Serkeşlikle imtina etti, benim gibisi, bir sabiye vezirlik etmez dedi. Sonra Belh mütevellisi oldu ve o memleketleri istilâ (o memleketlere tahakküm) etti. Bu esnada, sultanın cücesi (maskarası) olan Caferegin (Caferek) Isfehan'da, pederi Nizamülmülk aleyhinde söylendiğini ve vezirliğin, Behminyar oğluna kararlaştırıldığını işitti. Bunun üzerine hiddetlendi, galeyana geldi, Belh'ten süratle yürüdü. Sultan yanına geldi. Cafereği, sultanın huzurundan aldı ve kafasını yarıp dilini çıkarmalarını emretti. Caferek, o anda öldü. Bu hususta geniş bilgi için bkz. Bundârî, a.g.e., s. 73-74-75.
} 
Atların kuyruğunun bağlanması ve kesilmesiyle ilgili uygulamalar Türkiye Selçuklu Devleti zamanında da görülmüştür. Atların kuyruğunu kesmek hayvana acı veren bir iş olduğundan bazen de atın kuyruğunu kesme yerine yelesini kesip, kuyruğunu örme âdeti de uygulanırdı. Eski Türklerde mücadele başlamadan evvel alpler, atların kuyruklarını ipekle örüyorlardı ve bunu kahramanlık, mertlik sembolü kabul ediyorlard1. ${ }^{52}$

Türk kültürüyle alakalı hem tarih kaynaklarında hem de edebiyat kaynaklarındaki minyatürlerde canlandırılan mücadele sahnelerinin vazgeçilmez temalarından biri yine attır. Bu bağlamda atların kuyruğunu bağlama âdetinin Türkiye Selçukluları zamanındaki sanat eserlerine de yansıması gayet tabidir. $\mathrm{Bu}$ durum1220-1227 tarihli Konya Alâaddin Köşkü duvar çinisinden bir parçada da görülmektedir. Süvari figürün baş kısm1 kırıktır. Ayağında uzun sivri burunlu çizme kollarında beyaz geniş tiraz görülmektedir. Dört nala koşar vaziyette olan atın kuyruğu düğümlüdür. ${ }^{53}$

Konya Alâaddin Köşkü'nde karşılıklı iki süvarinin mücadelesini gösteren stuk panoda sağ taraftaki figür önden saldıran ejdere kılıcını saplamaktadır. Süvariler ay sembolü olan ejdere ve güneş sembolü olan aslana hâkim şekilde gösterilmektedir. Süvarilerin yuvarlak yüzleri, Orta Asya tipi çekik gözleri vardır. Başlarında börk şeklinde başlıklar taşırlar. Süvarilerin uzun askeri giyimleri bellerinde kemer ile toplanmıştır. Sivri burunlu uzun konçlu çizmeleri gayet belirgindir. Süvarilerin atlarının kuyruğu düğümlüdür. ${ }^{54}$

Atların kuyruğunu bağlama âdeti Türkiye Selçuklu sikkelerine de tesir etmiştir. IV. Rükneddin Kılıç Arslan dönemine ait 1249 yılında darp edilen gümüşs sikkenin bir tarafinda tasvir edilen süvarinin elinde üç bükümlü yay ve ilaveten yedek iki ok vardır ve atın kuyruğu düğümlüdür. $\mathrm{Bu}$ sikke atın kuyruğunu bağlama geleneğin Türkiye Selçukluları zamanında da sürdügünü teyit etmektedir. ${ }^{55}$

XIII.yy. eseri olarak tarihlendirilen Afyon Boyalı Köy'de bir türbenin sanduka şeklindeki mezar taşında at
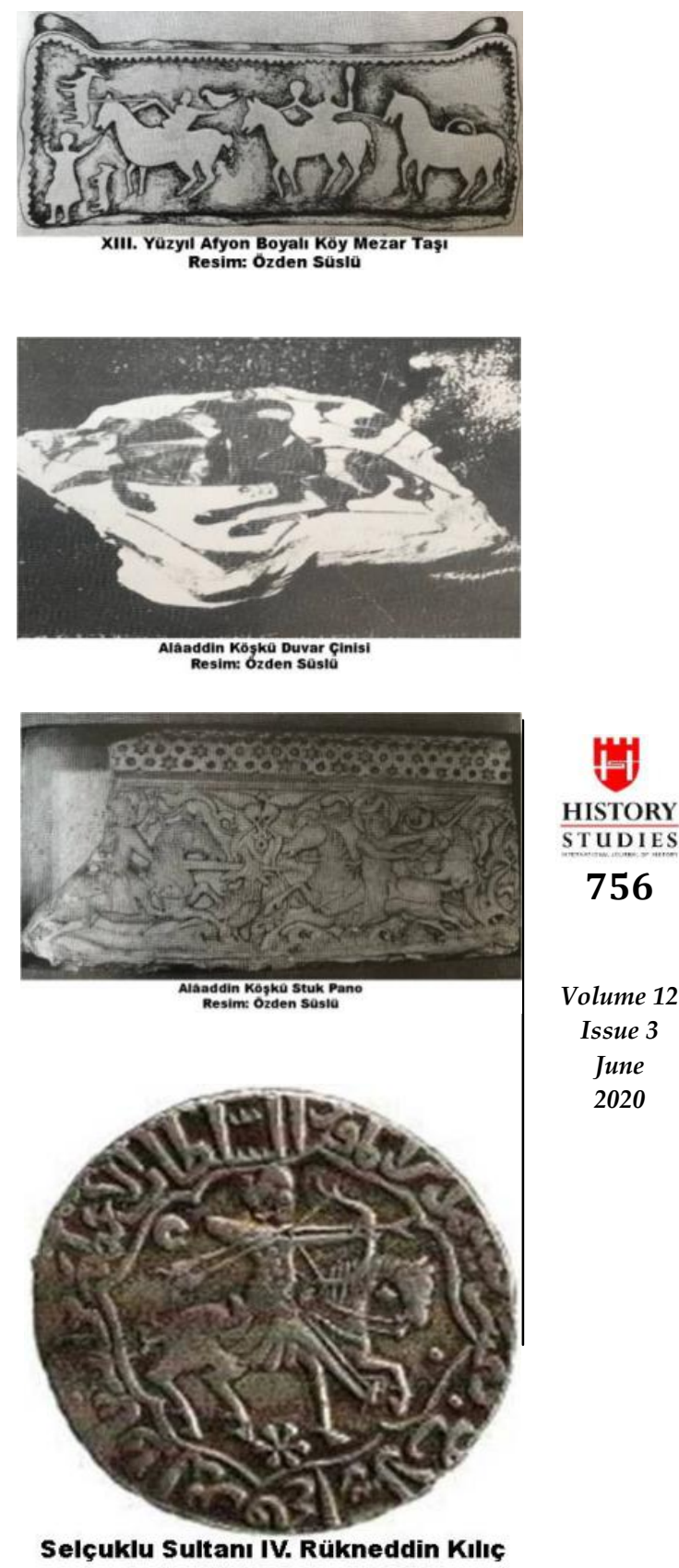

2020 kuyruğu bağlama âdeti görülmektedir. Zikzaklı bir çerçeve içinde, önde atın geminden tutmuş, cepheden görünen kaftanlı figür yer alır. At üzerindeki figür sol elinde şahin tutmakta, diğer

\footnotetext{
52 Kaşgarlı Mahmut, Divan-1 Lügati’t-Türk, II, (çev. Besim Atalay), TTK Yayınları, Ankara 1985, s. 349; Hacıgökmen, a.g.m., s. 407.

${ }^{53}$ Özden, Süslü, Tasvirlere Göre Anadolu Selçuklu Kıyafetleri, Atatürk Kültür Merkezi Yayınları, Ankara 2007, s. 63.

${ }^{54}$ Süslü, a.g.e.,s.96-97.

55 Tülay Metin, "Selçuklularda Okçuluğa Genel Bir Bakış", Tarih Okulu Dergisi (TOD), Yı1 7, sayı XVII, Mart 2014, s. 140 .
} 
eliyle de mızrağı av hayvanına saplamaktadır. Av hayvanları dikey olarak görülmektedir. İkinci atlının elinde, avda gürülttü yaparak kuşların havalanmasını sağlayan tokmağa benzer aletler görülmektedir. Davul gibi gürültü yapan alet edevat, şahinleri avlarken kullanılan araçlardır. En arkada süvarisiz bir at yer almaktadır ve ikinci süvari tarafindan dizginleri tutulmaktadır. Atların kuyrukları üç düğümlüdür. Taşın arka yüzündeki figürler harap vaziyettedir. İki atlı figür görülmekte ve öndeki atta yer alan figür bir eliyle atın gemini diğer eliyle de şahini tutmaktadır. Taşın bir tarafında ava çıkış, diğer tarafında ise avlanma anı canlandırılmıştır. ${ }^{56}$

Topkapı Sarayı Müzesi'nde bulunan ve XIII. yy. da yapılmış olan çelik Selçuklu aynasının ortasında atı üzerinde giden ve bir elinde şahin tutan avcı tasvir edilmiştir ve atın kuyruğu düğümlüdür. Tepesi hafifçe sivrilen basık bir başlık giymiş olan atlı, şahini tuttuğu eline eldiven

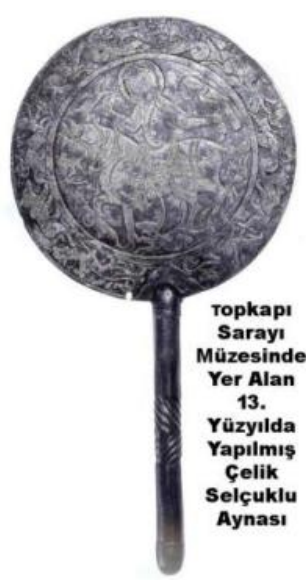
giymiştir. $^{57}$

Anadolu'da resimlenen ve en erken tarihli yazma olan Varka ve Gülşah isimli eserde Selçuklu resim sanatının en güzel örnekleri bulunmaktadır. Konya'da XIII. asrın başlarında hazırlanan eserin minyatürleri, Abdülmümin b. Muhammed el-Hoyî tarafından yapılmıştır. Metinlerin arasında yatay frizler halinde yer alan bu resimler, Anadolu Selçuklu minyatür üslûbunun karakteristik özelliklerini taşır. İslâm dünyasında çok sevilen bu mesnevinin Topkapı Sarayı müzesi kütüphanesinin hazine kısmında 841 numarada kayıtlı olan nüshası 70 varak tutmaktadır ve her varakta bir tane olmak üzere toplam 71 tane minyatür vardır. Eserde savaş sahnelerinden pek çok örnek vardır. Bu bilgiler ışı̆̆ında, Varḳa ve Gülşah'a kaydedilmiş minyatürlerde yer alan sahnelerdeki kuyruğu bağl1 veya dügümlü atlar, bu geleneğin Türkiye Selçukluları devrindeki yansıması olması açısından oldukça kıymetlidir. ${ }^{58}$
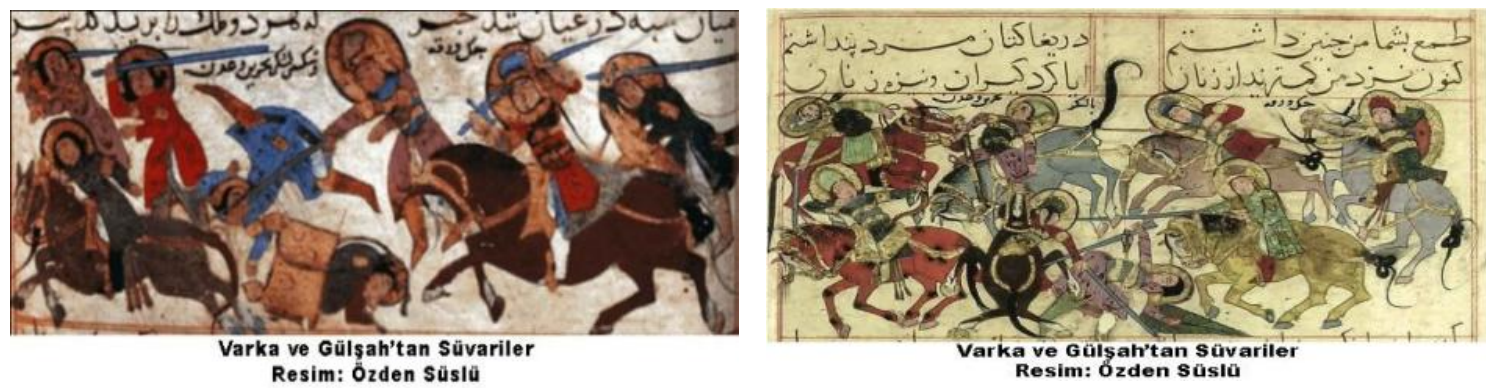

Varka ve Gülşah’ta yer alan bir minyatürde süvarilerin savaşını gösteren bir sahne, tam bir dinamizm içerisinde yansıtılmıştır. Süvarilerin bir kısmı savaş takımları içindedir, ellerinde kalkan ve kargı, başlarında ise miğferler gözükmektedir. Süvarilerin saçları örgülü, ön taraftan ve arkadan sarkar biçimde yansıtılmıştır. Askerlerin atlarının kuyrukları düğümlüdür. ${ }^{59}$

\footnotetext{
${ }^{56}$ Süslü, a.g.e., s. 107-108.

${ }^{57}$ Nurhan Atasoy, "Selçuklu Kıyafetleri Üzerine Bir Deneme”, İstanbul Üniversitesi Edebiyat Fakültesi Sanat Tarihi Ylllı̆̆l, sayı.4, 1970-1971, s. 125, 126, 127, 128, 129.

${ }^{58}$ Emine Gürsoy Naskali, Türk Kültüründe At ve Çağdaş Atçılık, Türkiye Jokey Kulübü Yayınları, İstanbul 1995, s.173; Ahmet Ateş, "Farsça Eski Bir Varka ve Gülşah Mesnevisi", İstanbul Üniversitesi Edebiyat Fakültesi Türk Dili ve Edebiyatı Dergisi, c.5, sayı 5, 3 Temmuz 2012, s.38-41; Yusuf Öz, "Varaka ve Gülşah", DİA, c. XXXXII, İstanbul 2012, s.515-516.

${ }^{59}$ Süslü, a.g.e., s.32.
} 


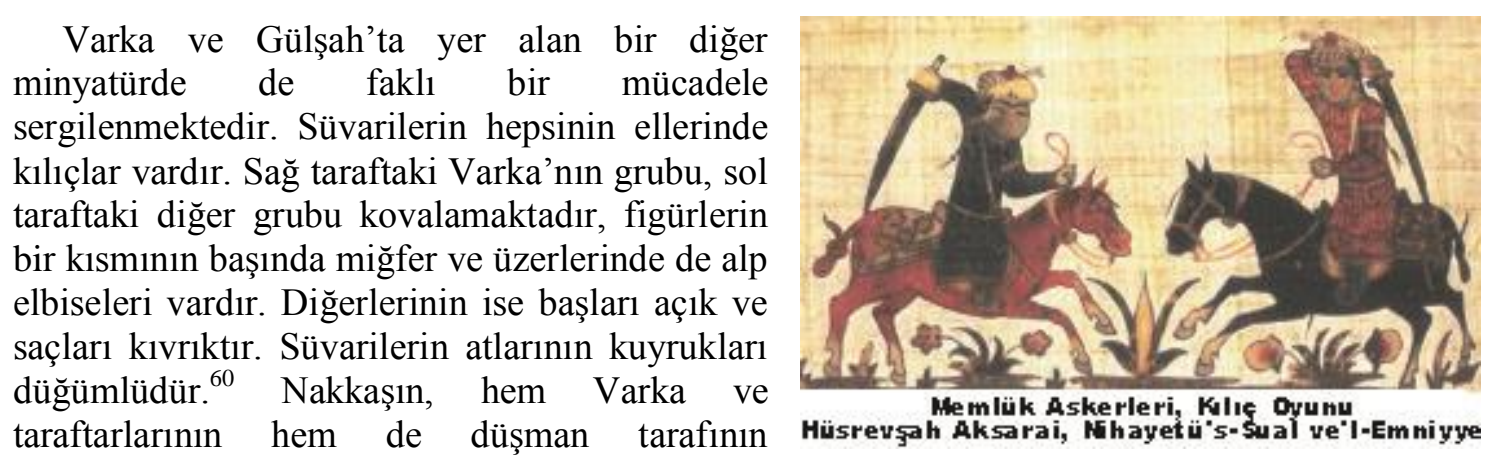
askerlerini resmederken olabildiğince Türklerin makbul kabul ettiği farklı renklerde ve cinste atları göstermeye gayret ettiği anlaşılmaktadır. Varḳa ve Gülşah isimli eserde bulunan bilgiler ve minyatürler at kuyruğu bağlama geleneğinin bu dönemde de canlı bir şekilde devam ettiğini göstermektedir.

$\mathrm{Bu}$ uygulamanın bir örneği de Memlükler (1250-1517) zamanında görülmektedir. Memlük ordusunun eğitimindeki faaliyetleri betimleyen Hüsrevşah Aksarayi'nin kitabındaki minyatürlerde dikkat çeken bir detay, atların kuyruklarının bağlı olmasıdır. ${ }^{61} \mathrm{Bu}$ uygulamanın geniş Türk coğrafyası içerisinde tarihteki önemli Türk devletlerinden biri olan, İslam âleminin batısını Moğol saldırılarından koruyan ve Suriye topraklarındaki haçlıları ortadan kaldıran Memlükler zamanında da görülmesi Türk kültürünün yayıldığı sahanın genişliğini ve etkisini anlamamız açısından önemlidir.

At kuyruğunun bağlanması geleneği Türk coğrafyasının kuzey bölgelerinde de kendisini göstermektedir. Altın Orda Devleti'nin tarih sahnesinden silinmesinden sonra Karadeniz'in kuzeyinde Kıpçak Bozkırı'nda siyasi bir teşekkül olarak ortaya çıkan Kırım Hanlığı askerlerinin ve özellikle süvarilerinin bu geleneğin yaşattığını görmekteyiz. Kırım Tatarlarından bir Türk süvarisinin tasvir edildiği çizimde, at üstündeki süvarinin belinde bir sadak asılıdır ve sadağın içine oklar yerleştirilmiştir. Süvari, yayını germiş atışa hazır vaziyettedir ve atının kuyruğu bağlanmıştır. ${ }^{62}$

$\mathrm{Bu}$ uygulama Osmanlı Devleti devrinde de sürmüştür. Örneğin, II. Mehmet'in defin merasimini, Sarıca Kemal şöyle aktarmaktadır: "Hezarat kuyruğunu kestilerdi. Nice kurulu yay yastılard ". Benzer bir uygulama da Fatih Sultan Mehmet zamanında görülmüsşür. Fatih'in babası II. Murat'ın vefatın da defin merasimine katılanlar, atlarının kuyruklarını kesmişler, eyerlerini ters çevirdikleri gibi, yaylarını kırıp tabutun üzerine bırakmışlardır. Başka bir örnekte ise, Yavuz Selim'in yeğeni

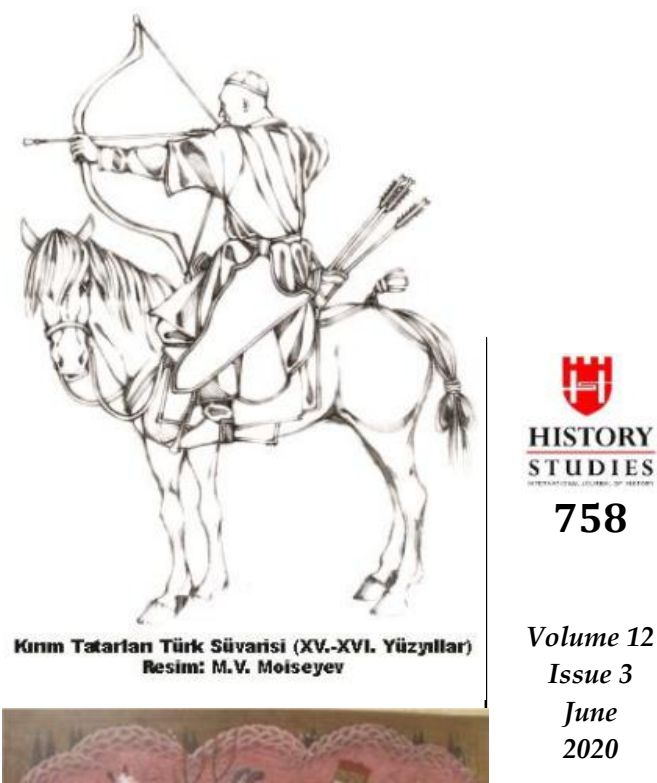

${ }^{60}$ A.g.e., s.32.

${ }^{61}$ Ahmet Özdal, Türklerin Savaș Sanatı, Doruk Yayıncılık, İstanbul 2008, s.140.

${ }^{62}$ M.V. Moiseyev, "Stepniye Voynı ot Ugr1 do Nogayskogo Pograma Krima 1480-1522", Stoyaniye na Reke Ugre 1480-2015, Cilt I, San-Petersburg 2015, s.175. 
Süleyman Bey 1513 senesinde Misır'da öldüğü zaman, defin merasiminde tabutun önüne kuyrukları kesilmiş ve eyerleri ters çevrilmiş atlar götürülmüştür. Süleyman Bey'in kırılmış yayları ve sarığı da tabutun üzerine bırakılmıştır. ${ }^{63}$ Yine Kanunî Sultan Süleyman (1520-1566) dönemine ait Arifî’nin Topkap1 Sarayı müzesi kütüphanesi H.1517 no'da yer alan,1558 tarihli Süleyman-nâme isimli eserinde 575a'da Kanunî Sultan Süleyman, Heme civarında Şehzade Selim'in avını izlerken resmedilmiştir. Minyatürde Kanunî Sultan Süleyman elinde doğanıyla kır at üzerinde resmedilmiştir ve avı izlemektedir. Her bir avcının farklı tarafa koşan atlarının kuyrukları düğümlüdür. ${ }^{64}$

\section{Sonuç}

$\mathrm{Bu}$ çalışma, at kuyruğunun bağlanması ve kesilmesi ile ilgili geleneği bütün yönleriyle detaylı olarak açılamaktan ziyade, bu geleneğin tarihi süreç içerisindeki seyrini genel hatlarıyla açıklamaya çalışmıştır. Zira meselenin daha ayrıntılı ve detaylı açıklanması daha büyük bir çalışma konusudur. Bu gelenek açıklanmaya çalışılırken de eski dönemlerden Osmanlı'ya kadar Türk tarihinin çeşitli dönemlerinde görülen uygulamalarından örnekler verilmiştir.

Her milletin kendine has kültürel değerleri vardır. Milletlerin bu kültürel değerleri, içerisinde yaşadıkları coğrafyaya veya yaşam tarzına göre şekillenir. Kültürün şekillenmesine etki eden bu unsurlar aynı zamanda birtakım öğeleri, kavramları veya nesneleri de öne plana çıkarır. Türklerin kültürel hayatlarında ise yaşadıkları bozkır coğrafyası ve savaşçılık özellikleri dolayısıyla at, öne çıkan bir değer olarak kendini göstermektedir. At, bir Türk süvarisi için hem bu dünyada hem de ölümünden sonra diğer dünyada silah arkadaşı ve yoldaşı olarak değer kazanmıştır. $\mathrm{Bu}$ vesileyle at merkezli uygulamalar Türk kültüründe geniş yer tutar. Türk kültürünün birçok alanına yerleşmiş olan atla ilgili gelenekler ise Türklerle birlikte onların yaşadıkları ve yayıldıkları her yere taşınmıştır. Bunun sonucunda çok büyük bir coğrafyada atla ilgili uygulamalardan birisi olan at kuyruğu bağlama geleneği görülmeye başlamıştır. Türk tarihini bir bütün olarak ele aldığımız zaman tarih boyunca, farklı coğrafyalarda, farklı tarihlerde birçok hanedanlık, beylik ve devlet kuran Türkler, gerek İslamiyet öncesi gerekse İslamiyet sonrası dönemlerde yayıldıkları coğrafyalarda öz kültürlerini muhafaza etmişlerdir. İskitlerden beri devam ede gelen at kuyruğu bağlama geleneği de bu kültürel devamlılığın bir simgesi, bir parçası olmuş ve hemen hemen bütün Türk devletlerinin kültürel hayatlarında görülmüştür.

At kuyruğunun bağlanması ve kesilmesiyle ilgili uygulamalar genel olarak ölüm ve savaş durumlarında görülmüştür. Durum böyle olunca bu geleneğin inanç sistemi ve kahramanlık düşüncesiyle olan bağlantısı akla gelmektedir. Yazılı kayıtların az olduğu eski dönmelerde genellikle kurganlarda görülmesi veya bilgilerimizin sadece arkeolojik kazılardan ibaret olması sebebiyle inanç sistemi içerisinde değerlendirilmektedir. Bunun en açık örneklerinden birisini Altay'daki Pazırık kurganları oluşturmaktadır. Ancak burada birtakım sorular da akla gelmektedir. Atın kurban olarak en makbul hayvan sayıldığı eski dönemlerde, ölüm adetleri dışında at kuyruğunun kesilmesi ve bağlanması ile ilgili uygulamalar var mıydı? Günlük hayattaki birtakım zamanlarda veya bayramlar, dini törenler gibi özel günlerde de at kuyruğu bağlanmakta ya da kesilmekte miydi? Bütün bunlar yazılı kaynakların olmadığı dönemler açısından cevapsız kalmaktadır. Bu dönemlerle ilgili bilgilerimiz arkeolojik kazılardan ibaret olduğu için atın kuyruğunun bağlanması ve kesilmesini ölüm adetleri çerçevesinde görmekteyiz. Bundan dolayı atların kuyruklarının bağlanması veya kesilmesini Türk kültür

${ }^{63}$ Hacigökmen, a.g.m., s. 406.

${ }^{64}$ Gürsoy Naskali, a.g.e., s.174. 
hayatındaki yas alametlerinden birisi olarak değerlendirmekteyiz. Bu uygulama en eski devirlerden beri yapılmıştır. Eski dönemlerde yazılı kaynağın az olmasından dolayı genellikle kurganlarda tespit edilen bu gelenek daha sonraları savaş, kahramanlık, ölüm gibi durumlarda görülmüş̧ür. Bu yüzden at kuyruğu; evde, otağda, kurganlarda, Alplerin mızrakları ucunda, tuğ yapımında, sırıkların ucuna takılmış vaziyette mezarların başında görülmüştür. $\mathrm{Bu}$ yas alametine göre; ölünün hayattayken bindiği atın yelesi ve kuyruğu kesilir, atı da kurban edilerek kendisiyle birlikte mezarına yerleştirilirdi. Bu uygulama, savaşçının en yakın dostu ve yoldaşı olan, savaş arkadaşı olan atın ölümden sonra da onunla birlikte diğer dünyaya gideceği ve ona hizmet etmeye devam edeceği inancindan kaynaklanmaktaydı. Atın kurban edilerek sahibi olan süvari ile birlikte bu şekilde kurganlara gömülmesi daha çok eski dönemlerde görülmüştür.

Daha sonraki dönemlerde özellikle İslamiyet'in kabul edildiği zamanlarda ve yazılı kaynakların bilgi verdiği dönemlerde atın kuyruğunun bağlanması ve kesilmesini ölüm adetleri ve savaş durumlarında görmekteyiz. Burada "atın kuyruğu ne zaman ve neden bağlanmaktaydı? Atın kuyruğunun kesilmesinin sebebi neydi? gibisinden birtakım sorulara cevaplar bulabilmekteyiz. Ölüm durumunda atın kuyruğunun bağlanması ve kesilmesi şüphesiz geçmişten gelen âdetin devamıdır ve Osmanlı dönemi de dahil olmak üzere yakın geçmişimize kadar devam etmiştir. Ancak eski dönemlere göre birtakım değişiklikler de görülmüştür. Sonraki dönemlerde atın kuyruğunun kesilmesi geleneği devam etmekle birlikte, artık at kurban edilmemeye başlanmış, bunun yerine kuyruğu kesilen at doğaya bırakılmıştır. Serbest bırakılan bu kuyruğu kesik atlara kimse binemez ve dokunamazdı. Bu uygulama tullamak olarak bilinir, sahibi olan süvari öldüğü için atın da $d u l$ kaldığı kabul edilirdi. Kesilen kuyruk ise bir sırığın ucuna takılmak suretiyle tuğ yapılır ve süvarinin/savaşçının mezarı üzerine dikilirdi. Kuyruğu kesilip doğaya salınan at da Tanrıya kurban olarak sunulmuş olmaktaydı. Bu durum kansız kurban örneğini göstermekte ve eski dönemlerdeki at kurbanının biraz değişikliğe uğrayarak yansımasını oluşturmaktaydı.

Bununla birlikte bir diğer mesele; "savaşlarda atın kuyruğunun bağlanmasının sebebi neydi?"

Burada, süvarinin/savaşçının henüz hayattayken atının kuyruğunu kendi eliyle bağladığını görmekteyiz ve bu gelenek de yine hemen hemen tüm Türk devletlerinde görülen bir uygulama olarak karşımıza çıkmaktadır. Atın kuyruğunun bizzat sahibi tarafından bağlanması geleneği genellikle savaş zamanlarında görülmüştür. Süvarinin kendi atının kuyruğunu kendi eliyle bağlaması, çetin bir savaşa çıkıldığı ve bu savaşta süvarinin kendisini şahadete atadığı anlamına gelmekteydi. Bu uygulamanın en açı örneğini Sultan Alparslan'ın Malazgirt Savaşı'na başlamadan önce yaptı̆̆ davranışta görmekteyiz. Atının kuyruğunu bağlayan Sultan Alparslan, bunu yaparken de eğer ölürse atının kuyruğunun bağlandığı yerden kesilmesini tembih etmiştir. Eğer süvari bu savaşta ölürse, atın kuyruğu, sahibinin bizzat kendi eliyle bağladığı yerden kesilirdi. Böylece kuyruğu kesilen at dul kalır ve sahibinin savaşta öldüğünü bu simgeyle belirtirdi. Sonuç olarak Türk kültüründe at kuyruğu kesme ve bağlama geleneği ilk zamanlardan beri Türk kültür ve medeniyetinin yayıldığı muhtelif sahalarda ve Türk Devletleri arasında canlı bir şekilde devam etmiştir.

\section{Kaynakça}

Ahmed b. Mahmûd, Selçuk-Nâme, haz. Erdoğan Merçil, İstanbul 1977.

ARTAMONOV, M.İ., Sokrovişa Sakov, Moskova 1973, s.40,44.

ATASOY, Nurhan, "Selçuklu Klyafetleri Üzerine Bir Deneme”, İstanbul Üniversitesi Edebiyat Fakültesi Sanat Tarihi Yıllığ 
ATEŞ, Ahmet, "Farsça Eski Bir Varka ve Gülşah Mesnevisi", İstanbul Üniversitesi Edebiyat Fakültesi Türk Dili ve Edebiyatı Dergisi, c.V, say1 5, İstanbul, 2012.

BOKOVENKO, N.A.-P.Ye. Mityayev, "Afanasyevskiy Mogilnik Malinoviy Log na Eniseye”, Afanasyevskiy Sbornik, Barnaul, Azbuka, 2010, s.16-29.

BUNDÂRÎ, Zübdetü'n-nusra ve Nuhbetü'l-usra, çev. Kıvameddin Burslan, Irak ve Horasan Selçukluları Tarihi, TTKY, Ankara 1999.

GAYDUÇENKO, L.L.-K.Yu. Kiryuşin, "Prigarı İz Keramiçeskih Sosudov Poseleniya Novoilinka-III v Severnoy Kulunde", Arheologiya Zapadnoy Sibiri i Altaya: Opıt Mejdistsiplinarnıh Íccledovaniy, Barnaul, 2015, s.106-110.

GÖMEÇ, Saadettin Y., "Türk Kültüründe At”, Uluslararası Sempozyum: Geçmişten Günümüze Bozktr, Selçuk Üniversitesi Yayınları, Konya, 2016, s.819-834.

GRYAZNOV, M.P., “Andronovskaya Kultura”, Arheologiya SSSR, Moskova-Leningrad, 1966.

GÜRSOY NASKALİ, Emine, Türk Kültüründe At ve Çağdaş Atçıllk, Türkiye Jokey Kulübü Yayınları, İstanbul 1995.

HACIGÖKMEN, M. Ali, "Türklerde Yas Âdeti Temelleri ve Sonuçları”, Tarihçiliğe Adanmış Bir Ömür Prof. Dr. Nejat Göyünç'e Armağan, Konya 2013, Selçuk Üniversitesi Türkiyat Araştırmaları Enstitüsü Yay, s.407.

Hamdullah Müstevfî-yi Kazvinî, Târih-i Güzide, çev: Mürsel Öztürk, TTKY, Ankara 2018.

İbn Kesîr, el-Bidâye ve'n-nihâye, çev. Mehmet Keskin, İstanbul 1995.

Volume 12

İbnü'l-Cevzî: el-Muntazam fì tarihi'l-mülûkve'l-ümem, çev. Ali Sevim, Makaleler, Ankara 2005.

İbnü'l-Esîr, el-Kâmil fi 't-tarih, çev. Abdülkerim Özaydın, Bahar Yayınları, İstanbul 1991.

KAFESOĞLU, İbrahim, "At”, TDV İslam Ansiklopedisi, Cilt 4, Türkiye Diyanet Vakfı Yayınları, İstanbul 1991, s.26-28.

-, Büyük Selçuklu İmparatoru Sultan Melikşah, MEB, İstanbul 1973.

, Türk Millî Kültürü, Ötüken Yayınları, İstanbul 1998.

Kaşgarlı Mahmut, Divan-ı Lügati't-Türk, II, (çev. Besim Atalay), TTKY, Ankara 1985.

KIZLASOV, L.R., “Afanasyevskaya Epoha v İstorii Hakasii”, Vestnik Moskovskogo Universiteta, Say1 2, Moskova, 1971, s.66-75.

KİLUNOVSKAYA, M.Ye., "Novıye Petroglifı na Yujnom Sklone Vostoçnogo Tannu-Ola v Tuve", Arheologiya Yujnoy Sibiri, Kemerova, 2011, s.86-90.

KİRYUŞIN, Yu. F., Eneolit i Rannaya Bronza Yuga Zapadnoy Sibiri, Barnaul, 2002.

KİRYUŞIIN, Yu.F.-S.P. Gruşin, "Hozyaystvo Naseleniya Andronovskoy Kulturı Verhnego Priobya", Hozyaysvenno-Kulturniye Traditsii Altaya v Epohı Bronzı, Barnaul, 2010, s.86-95.

KOCA, Salim, Selçuklular'da Ordu ve Askeri Kültür, Berikan Yayınevi, Ankara 2005.

KOSINTSEV, P.A.-N.F. Stepanova, "Fauna Afanasyevskogo Paselelniya Maliy Dugan", Afanasyevskiy Sbornik, Barnaul, Azbuka, 2010, s.121-129. 
KOVTUN, İ.V., "Nonfigurativnost Andronovskogo İskusstva: İdei, Faktı, İnterpretatsii", İzestiya Altayskogo Gosuderstvennogo Universiteta, Cilt 4, Say1 60, 2008, s.95-101.

KÖYMEN, Mehmet Altay, Tuğrul Bey ve Zamanı, Kültür Bakanlığı Yayınları, İstanbul 1976.

KUZMINA, Ye.Ye., Otkuda Prişli İndoarii, Moskova, 1994.

LATTIMORE, Owen, Studies in Frontier History Collected Papers 1928-1958, Oxford Üniversitesi Yayınları, Londra 1962.

LEONTYEV, N.V., "Kolesniy Transport Epohi Bronzı na Yeniseye”, Voprosı Arheologii Hakasii, Abakan, 1980, s.65-84.

METiN, Tülay, "Selçuklularda Okçuluğa Genel Bir Bakış", Tarih Okulu Dergisi (TOD), Yıl 7 , say1 XVII, Mart 2014, s.140.

MiLYAYEV, G.A., "Model Jivotnovodstva Andronovskogo Obşestva po Materialam Poseleniy Vostoçnogo Kazahstana", Arheologiya Zapadnoy Sibiri i Altaya: Opıt Mejdissiplinarnıh Íssledovaniy, Barnaul, 2015, s.232-237.

MOİSEYEV, M.V., "Stepniye Voynı ot Ugrı do Nogayskogo Pograma Krıma 1480-1522", Stoyaniye na Reke Ugre 1480-2015, Cilt I, San-Petersburg 2015.

ÖGEL, Bahaeddin, İslamiyetten Önce Türk Kültür Tarihi (Orta Asya Kaynak ve Buluntularına Göre), TTK Yayınları, Ankara, 1984.

--,Türk Kültür Tarihine Giriş VI, T.C. Kültür Bakanlığı Yayınları, Ankara, 2000.

ÖZ, Yusuf, "Varaka ve Gülşah”, DIA, c. XXXXII, İstanbul, 2012.

ÖZDAL, Ahmet, Türklerin Savaş Sanatı, Doruk Yayıncılık, İstanbul 2008.

PIYADEOĞLU, Cihan, "Büyük Selçuklular Dünyasında Yas Tutma Âdetleri ve Taziye Üzerine Merasimler", Trakya Üniversitesi Edebiyat Fakültesi Dergisi, c.2, sayı.3, Ocak2012.

, Sultan Alp Arslan Fethin Babası, Kronik Yayıncılık, İstanbul 2016.

PODOBED, V.A.-A.N. Usaçuk-V.V. Tsimidanov, "Tupiki v Kulturah Bronzovogo Veka", Arheologiya Zapadnoy Sibiri i Altaya: Optt Mejdistsiplinarnih İcledovaniy, Barnaul, 2015, s.255-261.

POLOSMAK, N.V., Vsadniki Ukoka, Novosibirsk, 2001.

Reşîdüddîn Fazlullah, Câmiu 't-tevârîh, çev. E. Göksu-H. H. Güneş, Selenge Yayınları, İstanbul 2010.

RUDENKO, S.İ., Pyatıy Pazırıksky Kurgan, Moskova-Leningrad, 1951.

, Vtoroy Pazırıkskiy Kurgan, Leningrad 1948.

Sadreddîn el-Hüseynî, Ahbârü'd-Devleti's-Selcukiyye (Zübdetü't-tevârih), çev. NecatiLugal, TTKY, Ankara 1999.

SAMAŞEV, Zaynolla, Drevneturkskaya Grafika, Astana, 2013.

--, "Kon v Ritualno-Obradovoy Praktike u Drevnego Naseleniya Kazahskogo Altaya", Türik Düniyesi, Almat1, 2013, s.616-625.

SEVIM, Ali, “İbnü’l-Kalânisı̂’nin Zeylü Tarih-i Dımaşk Adlı Eserinde Selçuklularla İlgili Bilgiler I. (H. 436-500-1044/45-1106/07)”, TTK Belgeler, Cilt XXIX, Say1 33, 2008. 
--------, "Malazgirt Muharebesi”, DIA, c. XXVII, Ankara 2003, s.481-483.

---------, Malazgirt Meydan Savaşı, TTKY, Ankara 1971.

SEVIM, Ali-Erdoğan Merçil, Selçuklu Devletleri Tarihi, TTKY, Ankara 1995.

Sıbt İbnü'l-Cezvî, Mir'âtü'z-zamân Fî tarihi'l- 'Âyân, çev. Ali Sevim, Makaleler II, Berikan Yayınları, Ankara 2005

SÜMER, Faruk, Oğuzlar (Türkmenler) Tarihleri-Boy Teşkilâtı-Destanları, Ankara Üniversitesi Dil ve Tarih-Coğrafya Fakültesi Yayınları, Ankara 1972.

SÜMER, Faruk-Ali Sevim, İslam Kaynaklarına Göre Malazgirt Savaşı (Metinler ve Çevirileri), TTKY, Ankara 1971.

SÜSLÜ, Özden, Tasvirlere Göre Anadolu Selçuklu Kıyafetleri, Atatürk Kültür Merkezi Yayınları, Ankara 2007.

ŞEŞEN, Ramazan, İbn Fadlan Seyahatnamesi, Yeditepe Yayınları, İstanbul, 2019.

ŞULGA, P.İ., "Novıye Materialı po Afanasyevskoy Kulture v Basseyne Çarışa”, Severnaya Yevraziya v Epohu Bronzl: Prostranstvo, Vremya, Kultura, Barnaul, 2002, s.150-154.

ŞULGA, P.İ., "O Hozyaystve Afanayevtsev Gornogo Altaya", Afanasyevskiy Sbornik II, Barnaul, Azbuka, 2012, s.204-210.

TIŞKIN, A.A.-P.K. Daşkovskiy, Sotsialnaya Struktura i Sistema Mirovozreniy Naseleniya Altaya Skifskoy Epohi, Barnaul, 2003.

TURAN, Osman, Selçuklular Tarihi ve Türk-İslâm Medeniyeti, Turan Neşriyat Yurdu, İstanbul 1969.

TURİNA, Ye.A., "İstoriya İzuçeniya Hozyaysva Naseleniya Afanasyevskoy Kulturı", Hozyaysvenno-Kulturniye Traditsii Altaya v Epohı Bronzı, Barnaul, 2010, s.12-20.

Urfalı Mateos, Vekayi-Nâme (952-1136) ve Papaz Grigor'un Zeyli (1136-1162), (Çev. Hrant D. Andreasyan), TTKY, Ankara 2000.

ÜNAL, Fatih, "Kazak Türklerinde Defin Merasimi ve Aş Verme Geleneği”, Bilig, Sayı 45, Bahar 2008.

YERMOLOVA, N.M., "K voprosu o Sibirskom Tsentre Odomaşnivaniya Loşadey”, İzuçeniya po Mezolitu i Neolitu SSSR, Leningrad, 1983, s. 188-191. 